\title{
Where the snails have no name: a molecular phylogeny of Raphitomidae (Neogastropoda: Conoidea) uncovers vast unexplored diversity in the deep seas of temperate southern and eastern Australia
}

\author{
Criscione Francesco ${ }^{1,{ }^{*}}$, Hallan Anders ${ }^{1}$, Puillandre Nicolas ${ }^{2}$, Fedosov Alexander ${ }^{3}$
}

${ }^{1}$ Australian Museum, Sydney NSW, Australia

2 Institut Systématique Evolution Biodiversité (ISYEB), Muséum national d'Histoire naturelle, CNRS, Sorbonne Université, EPHE, Université des Antilles. CP, Paris, France

${ }^{3}$ A. N. Severtsov Institute of Ecology and Evolution of Russian Academy of Sciences, Moscow, Russia

* Corresponding author : Francesco Criscione, email address : francesco.criscione@austmus.gov.au

\begin{abstract}
:
Although raphitomid snails are a dominant component of gastropod communities in deep seas worldwide, their systematics is still largely tentative. We assembled the most complete sampling of Raphitomidae from south-eastern Australia to date. Based on morphological and molecular data from this material, we produced a robust phylogenetic framework and used it to delimit genera. For the focus area, our results show a large proportion of undescribed species- and genus-level taxa, 11 of which are formally described herein. We demonstrate that the examination of purely morphological characters rarely suffices for the purpose of accurate genus delimitation. As a result, some traditionally highly diverse raphitomid genera (such as Gymnobela) turn out to be artificial assemblages of several unrelated, mostly undescribed, genus-level lineages. Our data suggest that comparable configurations of shell and radular features, observed at the genus level, commonly do not reflect true phylogenetic relationships. However, our results are inconclusive as to whether homoplasy or conservatism are the drivers of this phenomenon. Accommodating for the inevitable sampling biases, south-eastern Australia appears as a possible hotspot for both raphitomid diversity and endemism, when compared with adjacent areas.
\end{abstract}

Keywords : comparative anatomy, convergence, endemic, mtDNA, taxonomy, shell characters 
1 Introduction

2 Over a century after the expeditions of the Challenger, Albatross and Siboga (Watson, 1886;

3 Dall, 1908; Schepman, 1913), deep-sea exploration remains one of the major frontiers for

4 the discovery of marine mollusc biodiversity (Bouchet et al., 2016).

5 Over the last 35 years, deep-sea expeditions have been conducted across the Indo-Pacific

6 under the Tropical Deep-Sea Benthos (TDSB) programme, led by the Muséum national

7 d'Histoire naturelle (MNHN) (https://expeditions.mnhn.fr). These expeditions have revealed

8 a significant molluscan diversity, roughly projected to be in the order of $25-30,000$ species

9 for the south Pacific (Bouchet et al., 2008). An estimated 5,000 of these comprise the group commonly referred to as turriform conoidean gastropods. Turriform Conoidea, or simply

11 'turrids', is a conventional name used for the heterogenous assemblage including all but two

12 (Conidae and Terebridae) of the 18 currently recognised families in the neogastropod superfamily Conoidea Fleming, 1822 (Bouchet et al., 2009; Abdelkrim et al., 2018a).

Turriform Conoidea is the most diverse group of marine molluscs, with current estimates of 354 valid Recent genera and 3776 named Recent species (Horton et al., 2019). Maximum species diversity within turrids is found in offshore and deep-sea gastropod assemblages where, however, many species exhibit low abundance (Sysoev, 1997; Kantor et al., 2008; Bouchet et al., 2009). In general, turriform conoideans are characterised by considerable morphological homoplasy, with numerous cases where distantly related taxa exhibit almost identical shell shape and sculpture (Sysoev, 1997; Kantor et al., 2008; Bouchet et al., 2009). Because of their high diversity, low abundance and morphological complexity combined, the systematics of deep-sea turriform conoideans below family level remains tentative. Genera and species are diagnosed primarily based on morphology (e.g. Bouchet \& Warén, 1980; Sysoev \& Kantor, 1990; Sysoev, 1996a; Sysoev, 1996b; Sysoev, 1997; Bouchet \& Sysoev, 
2001; Sysoev \& Bouchet, 2001) and comparatively few genetic studies are available (e.g.

Puillandre et al., 2009; Puillandre et al., 2010; Fedosov \& Puillandre, 2012; Kantor et al. 2012; Kantor et al., 2016; Abdelkrim et al., 2018b; Kantor et al., 2018; Fassio et al. 2019; Hallan et al., 2019). However, such studies have challenged current species delimitations and highlighted pervasive genus-level paraphyly (e.g. Bouchet \& Warén, 1980; Sysoev \& Kantor, 1990; Sysoev, 1996a; Sysoev, 1996b; Sysoev, 1997; Bouchet \& Sysoev, 2001; Sysoev \& Bouchet, 2001; Puillandre et al., 2010; Kantor et al., 2018). Furthermore, a comparatively large proportion of deep-sea turriform conoideans still await description. For many areas, the number of undescribed species far outnumbers that of described species. For instance, it has been estimated that in New Caledonia, about $80 \%$ of deep-sea turriform conoideans are undescribed (Bouchet et al., 2008).

The family Raphitomidae Bellardi, 1875 (Bouchet et al., 2011), notably in the deep sea, are among the most poorly studied families of the group (Bouchet et al., 2011). The family comprises a total of 795 Recent accepted species in 65 Recent accepted genera (source WORMS, Horton et al., 2019). Nearly two-thirds of these genera (39), accounting for more than half of the overall raphitomid diversity (418 species), are found below the continental shelf. These figures are based on the notion that bathymetric preferences of turriform conoidean genera are exclusive of either deep- or shallow seas (Bouchet et al., 2009). The type species of almost half of the deep-sea raphitomid genera were described in the 19th century, with only four named after 2000. No molecular data has accompanied these descriptions, with anatomical data provided only occasionally (e.g. Sysoev \& Kantor, 1986; Sysoev, 1988; Kantor \& Sysoev, 1989; Sysoev \& Bouchet, 2001). For the vast majority of these genera, shell features are the only source of taxonomic information accessible from their type species. In addition, descriptions of most deep-sea raphitomids species have been 
provided in faunistic studies, aiming primarily to present the results of sampling campaigns in a given region and not necessarily to resolve the systematics. Consequently, generic attributions have been almost exclusively based on shell features and are therefore influenced by problems with character interpretation and undetected homoplasies. This issue has resulted in the current situation whereby only three genera contain approximately half of all accepted deep-sea raphitomid species. These genera (Pleurotomella Verril, 1872, 100 species; Gymnobela Verril, 1884, 75 and Xanthodaphne Powell, 1942, 33) have subsequently been colloquially addressed as "dumpsters", acting as provisional containers

57 for newly described species of problematic generic attribution. For instance, Sysoev \& Bouchet (2001, p. 305) state: "we somewhat arbitrarily include the yoshidai complex of species in Gymnobela".

Among the consequences of such unresolved systematics is a tentative status of the current biogeography of deep-sea raphitomids. A search of the Global Biodiversity Information reveals that they all occur outside the marine realm for which their type species was described. Most are found in several of the $\mathbf{3 0}$ marine realms (as delimited in Costello et al., 2017): Pleurotomella and Gymnobela occur in 18 and 19 realms respectively, Phymorhynchus Dall, 1908 and Taranis Jeffreys, 1870 occur in 15 realms, Xanthodaphne in 11, and Nepotilla Hedley, 1918 in 7. However, without adequate phylogenetic evidence, genus monophyly cannot be assessed, thus preventing appropriate biogeographical investigation. Assumptions of wide distributions at the genus level, as currently accepted, would be upheld only in a scenario where their monophyly is confirmed. However, large distributions of single genera are 
currently considered rare (Sigwart, Sutton \& Bennett, 2017). In the alternative scenario, any notion of wide distributions would be an artefact of genus paraphyly.

There has been no recent attempt to revise the systematics and biogeography of any deepsea raphitomid genus. However, this is now possible for the Raphitomidae of southern and south-eastern Australia, since suitable material has become available as a result of a number of expeditions aiming to quantify slope and abyssal biodiversity of the area (Fig. 1) (Maclntosh et al. 2018; Williams, 2018; O'Hara et al., unpublished data). These surveys have yielded a considerable amount of well-preserved gastropod material from depths ranging between approximately 900 and 5000 metres. Our preliminary identification of this material has revealed a predominant raphitomid component, consisting almost exclusively of undescribed taxa.

The present study combines morphological and molecular evidence generated from this newly available material in order to construct a robust phylogenetic framework with the aim to:

a) reconstruct phylogeny of Australian deep-sea Raphitomidae, with inclusion of taxa from adjacent regions, whenever possible and appropriate;

b) delimit and describe new deep-sea raphitomid genera from southern and eastern Australia, to facilitate subsequent taxonomic revisions;

c) explore the biogeographic patterns of the raphitomid fauna in the area and (when possible) compare these with those observed in other adjacent marine regions. 
92

93

94

95

96

97

98

99

100

101

102

103

104

105

106

107

108

109

110

111

112

113

114

Material and Methods

Sample processing

The study material was collected in a series of voyages along the Australian coast

(IN2015_C01, IN2015_C02, IN2017_C01, RE_2017, Great Australian Bight; IN2017_V03,

temperate east coast; IN_2018_V06, Tasmanian seamounts) (Fig. 1, Table 1). Additional

comparative shallow and deep-sea material of Raphitomidae was studied from other

geographic areas obtained through various expeditions: (a) SS10/2005 in southern Western

Australia (McEnnulty et al., 2011), (b) several voyages of the MNHN Tropical Deep-Sea

Benthos programme (Bouchet et al., 2016) (c) LAMPOS (Arntz \& Brey, 2003) and ANDEEP III

(Linse et al., 2007) in Antarctica, (d) AFRIDEEP in the south-western Indian Ocean (Türkay \&

Pätzold, 2009) (Table 1).

The material is deposited at the Australian Museum, Sydney, Australia (AMS), the Muséum national d'Histoire naturelle, Paris, France (MNHN), the South Australian Museum, Adelaide, Australia (SAMA), the Tasmanian Museum and Art Gallery, Hobart, Australia (TMAG), the Western Australian Museum, Perth, Australia (WAM) and the Bavarian State Collection of Zoology, Munich, Germany (ZSM).

Following collection, specimens were either anaesthetised with an isotonic solution of $\mathrm{MgCl}_{2}$ and fixed in $96 \%$ ethanol or directly transferred into $96 \%$ ethanol. Shells were subsequently drilled to extract the retracted animal. Alternatively, for MNHN post-2012 expeditions, specimens were exposed to microwaves, bodies removed from shells and then fixed in $96 \%$ ethanol as described in Galindo et al. (2014). All shells were photographed after fixation and (when not microwaved) prior to extraction of the animal. 
Taxon sampling

117 As a result of ongoing systematic research on the Conoidea at the AMS, over 200 (mostly unpublished) sequences of the mitochondrial gene COI have been obtained, following the protocol described below, from largely undescribed deep-sea raphitomid taxa primarily from southern and eastern Australia. In order to assist with the selection of the study material, the Automatic Barcode Gap Discovery (ABGD) methodology for primary species delimitation (Puillandre et al., 2012) was applied to a dataset containing all COI sequences. The web-based version of ABGD (http:// wwwabi.snv.jussieu.fr/public/abgd) was used with a K2P model. The relative gap width $(\mathrm{X})$ was set to 1 , with other parameters left to default. Resulting ABGD groups were considered species hypotheses for sample selection.

Subsequently, a subset of samples was constructed that incorporated: (a) a selection of non-

Australian species that represented at best the currently accepted supra-specific deep-sea raphitomid taxa (including, when possible, type species), (b) all Australian deep-sea raphitomid species as delimited by ABGD and (c) all Australian deep-sea raphitomid morphospecies for which COI data was not available. For each of the species of (a), (b) and (c), amplification of four additional genes (two mitochondrial - 16S rRNA and 12S rRNA; two nuclear - 28SrRNA and H3) was attempted. When available, additional $12 \mathrm{~S}$ rRNA, 28SrRNA and $\mathrm{H} 3$ sequences were sourced from GenBank (Table 1). The ingroup (on which phylogenetic analyses are based) was assembled by selecting one sample per species of (a), (b) and (c), subject to the availability of at least three out of the total five targeted markers. When possible, specimens used for morphological study (see below) were selected among molecular vouchers to ensure an objective linkage of morphological and phylogenetic information. 
140 From DNA extraction to sequencing

141 Molecular work was performed in laboratories at two institutions (AMS and MNHN). Unless

142 otherwise stated, the two laboratories followed the same methodology.

143 DNA was extracted from small pieces of foot muscle by using the Bioline Isolate II Genomic 144 DNA extraction kit for animal tissue, following the standard procedure of the manual (AMS) 145 or using the Epmotion 5075 robot (Eppendorf), following the recommendations of the 146 manufacturer (MNHN). A fragment of three mitochondrial genes [cytochrome oxidase 147 subunit I (COI), rRNA 12S (12S) and rRNA 16S (16S)] and of two nuclear genes [rRNA 28S 148 (28S) and histone $\mathrm{H3}(\mathrm{H} 3)]$ were amplified using the following primer pairs:

149 LCO1490/HCO2198 for COI (Folmer et al., 1994), 12S-I/12S-III for 12S (Simon et al., 1991), 150 16SH/16LC for 16S (Palumbi, 1996), C1'/D2 for 28S (Dayrat et al., 2001) and H3A/H3B for H3 151 (Okusu et al., 2003).

152 PCR reactions were performed in volumes of $25 \mu \mathrm{l}$, containing $3 \mathrm{ng}$ DNA, $1 \mathrm{X}$ Qiagen 153 CoralLoad PCR Buffer, $2.5 \mathrm{mM} \mathrm{MgCl}_{2}, 0.25 \mathrm{mM}$ dNTP, $0.5 \mathrm{mM}$ of each primer, $0.5 \mu \mathrm{g} / \mu \mathrm{l}$ of BSA 154 and $0.2 \mu \mathrm{l}$ of Bioline MyTaq DNA polymerase. For COI, 12S, 16S and H3, amplification 155 consisted of an initial denaturation step at $94^{\circ} \mathrm{C}$ for $4 \mathrm{~min}$, followed by 37 cycles of 156 denaturation at $94^{\circ} \mathrm{C}$ for $30 \mathrm{~s}$, annealing at respectively $50,57,55$ and $55^{\circ} \mathrm{C}$ for $30 \mathrm{~s}$, 157 followed by extension at $72^{\circ} \mathrm{C}$ for $1 \mathrm{~min}$. The final extension was set to $72^{\circ} \mathrm{C}$ for $5 \mathrm{~min}$. 158 Conditions for the $28 \mathrm{~S}$ fragment were as above, with the exception of 30 denaturation 159 cycles and annealing temperature set to $57^{\circ} \mathrm{C}$ for $45 \mathrm{~s}$ for the latter.

160 PCR products were purified and sequenced by the Macrogen (AMS) and Eurofins (MNHN) 161 sequencing facilities. Both strands of PCR fragments were purified with ExoSAP (Affymetrix) and cycle-sequenced by use of the PCR primers. Chromatograms were manually corrected 
for misreads, if necessary, and forward and reverse strands were merged into one sequence file using CodonCode Aligner v. 3.6.1 (CodonCode Corporation, Dedham, MA).

Phylogenetic analyses

Sequences were manually (COI and H3) or automatically (12S, $16 \mathrm{~S}$ and $28 \mathrm{~S}$ ) aligned using

MAFFT online (Rozewicki et al., 2017) by applying the automatic selection of the alignment

strategy. Where necessary, resulting alignments were refined by eye. Sequences were

deposited in GenBank and BOLD (Table 1). Turris babylonia (Linnaeus, 1758) (Turridae),

Lienardia mighelsi Iredale \& Tomlin, 1917 (Clathurellidae) and Citharomangelia

planilabroides (Tryon, 1884) (Mangeliidae) served as outgroups. Analyses were first

performed on each gene separately to check for inconsistency between trees (results not

shown). As no supported incongruences were found, all genes were concatenated in a single

dataset. Phylogenetic trees were reconstructed by implementing maximum likelihood (ML)

and Bayesian inference (BI) methods, using RAxML (Stamatakis, 2006) and MrBayes

(Ronquist \& Huelsenbeck, 2001) respectively. Both analyses were performed on the Cipres

Science Gateway (http://www.phylo.org/portal2), using RAxML-HPC2 on XSEDE and

MrBayes v. 3.2.2 on XSEDE. In all analyses the $16 \mathrm{~S}, 12 \mathrm{~S}$ and $28 \mathrm{~S}$ genes and the three codon

positions of the $\mathrm{COI}$ and $\mathrm{H} 3$ genes were treated as independent partitions, with the

substitution model set to $G T R+G$ and $G T R+G+I$ for the $R A x M L$ and MrBayes analyses,

respectively; the parameters of the substitution model were evaluated independently for each partition during the analyses. Robustness of the nodes of the ML trees was assessed using a bootstrapping procedure with 1,000 replicates. Each of the two runs of the $\mathrm{BI}$ analysis consisted of six Markov chains and 10,000,000 generations, with five chains, three swaps at each generation, a sampling frequency of one tree per 1,000 generations and a 
187 chain temperature set to 0.02 . Convergence of each analysis was evaluated using Tracer v.

188 1.4.1 (Rambaut et al., 2018) to check that all effective sample size values exceeded 200.

189 Consensus trees were calculated after omitting the first $25 \%$ trees as burn-in. Nodal support 190 was assessed as posterior probability in the BI analyses.

Morphological examinations

Shell morphology and when possible, internal anatomy, including radular morphology, were studied for at least one specimen for each of the Australian species.

We describe shell morphology using the terminology established by Röckel, Korn \& Kohn (1995). Descriptions are based on shells orientated in the traditional way, with the spire uppermost and with the aperture facing the viewer. Protoconchs were measured in standard position and the number of whorls counted according to Bouchet \& Kantor (2004). Maximum shell length (SL) and width (SW) were measured using a digital calliper and rounded to the nearest $0.1 \mathrm{~mm}$, with the number of whorls counted according to Bouchet \& Kantor (2004).

202 When removed from ethanol, animals were briefly rehydrated in distilled water. Using standard dissection tools, the foregut organ complex, comprising the proboscis, venom 204 gland, radula and salivary glands, was excised and the radular sac was isolated and placed on a glass slide. During the dissection process, head-foot, mantle, genital and (non-radula) foregut characters were examined where possible. After dissolution in diluted commercial bleach, clusters of hypodermic teeth where rinsed repeatedly in distilled water, then separated into individuals and ligament-connected pairs. Subsequently, the glass stub was affixed to a carbon adhesive placed on a $12 \mathrm{~mm}$ diameter aluminium mount. All samples 
210

211

212

213

214

215

216

217

218

219

220

221

222

223

224

225

226

227

228

229

230

231

232

233

were imaged at Macquarie University, Sydney, using a Phenom XL Scanning Electron Microscope.

\section{Genus delimitation and name application}

The genera were delimited according to the following criteria: (1) distinct genera form clades, (2) clades are well-supported (in terms of nodal support), (3) all species in a clade share a unique combination of morphological characters.

When sequences of the type species were not included in the analysis, genus attribution was guided by the co-occurrence in all sequenced specimens of diagnostic shell and radular (or other anatomical) features. When a combination of shell and radular characters, not previously observed in any named raphitomid genus, was shared by all species of a given clade, existing names were not considered applicable. For such clades, new genus names were introduced. When no anatomical data was available and no unequivocally typical shell traits could be observed, we refrained from introducing new genus names.

\section{Abbreviations}

$12 S=12 S$ ribosomal RNA gene; $16 \mathrm{~S}=16 \mathrm{~S}$ ribosomal RNA gene; $28 \mathrm{~S}=28 \mathrm{~S}$ ribosomal RNA gene; $\mathrm{BI}=$ Bayesian Inference; $\mathrm{COI}=$ Cytochrome $\mathrm{c}$ oxidase subunit I gene; dry = number of dry shell specimens; $\mathrm{CMR}=$ Australian Commonwealth Marine Reserve; GAB $=$ Great Australian Bight; $\mathrm{H} 3$ = Histone $\mathrm{H} 3$ gene; $\mathrm{Ht}$ = holotype; $\mathrm{ML}=$ Maximum Likelihood; $\mathrm{NSW}=$ New South Wales; NT = Northern Territory; OD = original designation of type species; $\mathrm{PNG}=$ Papua New Guinea; Pt = paratype; QId = Queensland; Tas = Tasmania; SL = shell length $(\mathrm{mm}) ; \mathrm{SW}=$ shell width $(\mathrm{mm}) ; \mathrm{VIC}=$ Victoria; $\mathrm{WA}=$ Western Australia; wet $=$ number of ethanol-preserved (wet) specimens. 
234 Results

235 Molecular analysis

236 In the vicinity of the barcode gap (Fig. S1), the ABGD analysis of the complete COI dataset

237 (200+ sequences) consistently returned a partition with 55 groups of sequences (Fig. S2).

238 Sequences of well-established and recognisable species, such as Spergo fusiformis (Habe, 239 1962), Famelica pacifica Sysoev \& Kantor, 1987 and Theta lyronuclea (Clarke, 1959) were 240 correctly grouped by ABGD (in red in Fig. S2), indicating that the inferred gap was reliable.

241 Amplification of at least two additional target genes (among 16S, 12S, 28S and H3) was

242 successful for (at least) one specimen of each of 50 of these species (in bold in Fig. S2). At

243 least three of the target markers were also amplified for 8 additional morphospecies not

244 included in the ABGD analysis due to missing COI sequences. A five-gene dataset was then

245 generated that consisted of sequences from these $58(50+8)$ Australian deep-sea species,

246 with 18 additional species of Raphitomidae from outside Australia and three outgroup

247 species from other conoidean families (Table 1). Of the total species included, 71 were from

248 deep water and five from shallow water. Most of the Australian species (51) were

249 undescribed. All except three could be assigned to 23 genera, 12 of which were

250 undescribed. Formal taxonomic descriptions of the type species of these newly recognised

251 genera are provided below. In the molecular analysis herein, type species of new genera are

252 represented by sequences of their holotype or of paratype material. Descriptions of

253 additional, non-type species will be presented in subsequent publications. These species are

254 labelled with a combination of the abbreviation 'sp.' and a number (1-5).

255 For clarity, the following molecular and anatomical comparisons are presented with

256 reference to existing and newly introduced taxon names. However, the underlying taxon

257 delimitations resulted from the combined assessment of the molecular and anatomical 
258

259

260

261

262

263

264

265

266

267

268

269

270

271

272

273

274

275

276

277

278

279

280

differentiation (see Discussion) and were not foregone conclusions preceding the analyses presented in this study.

Phylogenetic analyses were based on a total of 349 sequences (281 newly produced and 68 GenBank-sourced) consisting of: 73 12S sequences ( 65 new + 8 from GenBank), $7716 \mathrm{~S}$ sequences ( 65 new + 12 from GenBank), 54 28S sequences (39 new + 15 from GenBank), 69 COI sequences ( 52 new +17 from GenBank) and 76 H3 sequences ( 60 new +16 from GenBank). The final concatenated dataset of aligned sequences had a total length of 2,853 bp (12S: 600 bp, 16S: 536 bp, 28S: 731 bp, COI: 658 bp H3: 328 bp).

While most inferred clades were well-supported by both BI (Fig. 2) and ML trees (Fig. S3), a few of the deeper nodes remained unstable and (in some cases) lacked support. In addition, the occasional presence of polytomy can be attributed to the relatively limited taxon sampling. The description of the tree topology is presented below, with emphasis given to lineages that are consistently retrieved and supported by both analyses and that are relevant to the scope of this study.

All Raphitomidae clustered into three major monophyletic groupings in both $\mathrm{BI}$ and $\mathrm{ML}$ trees. Two of these clades, A and C, contained exclusively deep-sea taxa; the third clade, B, comprised shallow-water taxa (of which no Australian representatives were included in this analysis).

The smallest of the two deep-sea clades, A, included nine species in three described genera [Famelica Bouchet \& Warén, 1980 (3 species, 2 new), Rimosodaphnella Cossmann, 1916 (3 species, 2 new) and Veprecula Melvill, 1917 (1 known species)] and one previously undescribed genus [Glaciotomella n. gen n. sp. (2 species, both new)]. The latter genus was sister to a lineage comprising Veprecula cf. spanionema plus Rimosodaphnella spp. and 
281 Famelica spp. All specimens in this clade were collected in temperate Australia, except for $V$.

282 cf. spanionema (Philippines) and Rimosodaphnella sp. (New Caledonia).

283 Clade C contained all remaining deep-sea taxa, amounting to 62 species from 22 genera (11

284 known and 11 new), and 7 species not assigned to any genus. A dichotomy of $C$ separates a

285 small species cluster from a larger clade including the remaining samples.

286 The former cluster included exclusively unidentified species attributed to Pleurotomella,

287 with two from Antarctica and one from SE Australia comprising one subclade, and with one

288 from New Caledonia and one from Western Australia forming the other.

289 The larger clade was characterised by a basal polytomy, with four subclades containing

290 species of more than one genus, two clades including species of a single genus [Gladiobela

291 n. gen. (5 new species) and Pagodibela (4 new species)] and five species that did not cluster

292 with any other sample (Pueridaphne cirrisulcata n. gen. n. sp., Typhlosyrinx sp. and three

293 species unassigned to a genus). The first subclade contained 4 species in three new genera:

294 Fusobela n. gen. (possibly 2 new species - see below), Globodaphne pomum n. gen. n. sp.,

295 Trochodaphne cuprosa n. gen. n. sp. and one species unassigned to genus; the second

296 subclade included 10 species in three known genera: Gymnobela (4 new species),

297 Ponthiothauma E. A. Smith, 1895 (2 new) and Phymorhynchus (4 species, 2 new); the third

298 subclade comprised 2 unidentified species in 2 genera (Mioawateria Vella, 1954 and Taranis

299 Jeffreys, 1870) and the fourth subclade contained 3 species of uncertain generic attribution

300 and 23 species in 9 genera [Austrotheta n. gen. ( 2 new species), Spergo (6 species, 4 new, 1

301 unidentified), Theta (3 species, 2 new) and Austrobela (7 species, 6 new), Teretiopsis (1

302 unidentified) and Tatcheria (1 species) plus the monotypic Biconitoma n. gen., Aplotoma $\mathrm{n}$.

303 gen. and Nodothauma n. gen.] and]. 
Morphological analyses

Morphological examinations were conducted on all samples of deep-sea species from temperate Australia and form the basis for the taxonomic descriptions below. When possible and applicable, anatomical characters were assessed based on the holotype and on conspecific vouchers sequenced for mtDNA.

Shells, foregut (primarily the radula) and head-foot characters of all candidate genera were compared with features of other raphitomids where such characters are available in the literature, and by the examination of comparative material where necessary.

Of the new taxa, the shell morphology ranged from elongate-fusiform to biconical, and with sculptural elements including cancellate or with axial ribs, tubercles or spiral cords (Figs 3-4).

No sculptural elaboration or varix formation/thickening of the aperture, as that seen in some other raphitomid groups such as Hemilienardia O. Boettger, 1895 (Fedosov et al., 2017) was observed in the deep-sea taxa. Protoconchs, where available, were largely of the typical diagonally cancellate raphitomid type (Bouchet et al., 2011) (Fig. 5), but arcuate sculpture was also observed in species of Austrobela and Theta (Fig. 5D). Clarke (1959), reported this protoconch type for Theta lyronuclea, which formed part of his rationale to establish the (then) subgenus Theta.

Observed foregut morphologies ranged from the entire foregut complex (i.e. proboscis, salivary glands, venom gland and radula) being absent, to extremely large and occupying the majority of the rhynchocoel. The radulae, exclusively of the hypodermic type, varied from simple, awl-shaped without barbs or blades, with a single dorsal blade, to double-barbed (Fig. 6). Simple, awl-shaped teeth with or without a dorsal blade were more prevalent than double-barbed teeth. The morphology of the base varied from being only slightly broader than the basal portion of the shaft (the latter herein defining the tooth length without the 
329 base), to exhibiting a distinct lateral process, to very broad and angular. The size and shape 330 of the basal opening was generally homogenous; large, subcircular, and unrestricted

331 [compare to, for example, the restricted, lateral and ovate opening of Strictispiridae and 332 Bouchetispiridae (Bouchet et al., 2011; Kantor \& Puillandre, 2012; Hallan et al., 2019)]. The 333 external texture of the base ranged from very fine to very coarse (Fig. 6), whereas the length 334 of the adapical opening, and, where present, the dorsal blade, relative to the length of the 335 shaft ranged from short ( 0.1 ratio) to extremely long ( $\sim 0.5)$. Eyes were absent in only one 336 taxon (Biconitoma cretosa n. gen. n. sp.) and observed in all remaining taxa. The majority of 337 taxa exhibited small to minuscule eyes, whereas some possessed well-developed, large 338 eyes. 
339 Systematics

340 General remarks

341 If not stated otherwise, holotypes are dissected ethanol-preserved specimens and form the

342 basis of all systematic descriptions. The number of shell whorls is approximated to one

343 decimal unit. References to size are intended as relative to general patterns observed in the

344 Raphitomidae (see Bouchet et al., 2011). Shell and head-foot colouration reported in

345 descriptions are based on observations performed before fixation and may not be fully

346 reflected in the illustrations provided (Figs 3-5). Unless otherwise stated, the authorship of

347 the taxa described below corresponds to that of the present study.

348

349 Superfamily Conoidea Fleming, 1822

350 Family Raphitomidae Bellardi, 1875

351

352

Nodothauma n. gen.

353 Type species: Nodothauma magnifica n. gen. n. sp.: OD, herein.

354 Etymology: Derived from combination of 'nodos' (ancient Greek = toothless, for its lack of

355 radula) and 'thauma' (for its resemblance to Ponthiothauma).

356 ZooBank registration: urn:Isid:zoobank.org:act:86B1A839-13E6-45B5-8C77-8B8F8870FBBD

357

358 Diagnosis

359 Shell (Fig. 3A) large, fusiform, orange-brown. Early teleoconch whorls narrow in profile,

360 subsequent whorls somewhat broader in appearance, producing weakly concave shell

361 outline; shoulder pronounced. Subsutural ramp wide, bearing spiral cords and weak axial

362 riblets on its abapical portion. Siphonal canal long, tapering. Aperture large, elongate- 
363 pyriform. Columella with elongate burnt-orange stain. Anal sinus wide, u-shaped.

364 Rhynchocoel capacious, inner walls lined with dark red epithelium. Radula and venom

365 apparatus absent.

366

367 Nodothauma magnifica n. sp.

368 (Fig. 3A)

369

370

Material examined

371 Holotype: Australia, GAB, 1927 m, IN2015_C02_137, (-35.558, 134.083), AMS C.532707.

372 Paratypes: Australia, GAB, 1570 m, IN2015_C02_435, (-34.072, 130.267), 1 wet (SAMA

373 D44139); 1912 m, IN2015_C01_054, (-35.202, 131.629), 1 wet (SAMA D44255); 1509 m,

374 IN2015_C02_134, (-35.345, 134.045), 1 wet (AMS C.532689); 1509 m, IN2015_C02_134, (-

$37535.345,134.045), 1$ wet (AMS C.571573); 1 wet (AMS C.571637); 1927 m, IN2015_C02_137,

$376(-35.558,134.083), 1$ wet (AMS C.571739).

377

378 Distribution

379

Known only from the Great Australian Bight.

380

381 Etymology: In reference to its large shell, derived from 'magnificus' (Latin = majestic).

382

ZooBank registration: urn:Isid:zoobank.org:act:FE4DEFB1-2CB0-49DF-9C6C-9AA1042C2365

384

385

Description. Shell (Fig. 3A) large ( $\mathrm{H}=71.6 \mathrm{~mm}, \mathrm{~W}=24.9 \mathrm{~mm})$, elongate-fusiform, walls rather 386 solid, opaque. Protoconch eroded. Teleoconch of about seven orange-brownish whorls; 
387

spire outline slightly concave. Shoulder pronounced, situated slightly adapical to whorl midheight in early whorls, and indistinct on late teleoconch whorls. Subsutural ramp wide, concave to very lightly convex; suture impressed. Spiral sculpture below subsutural ramp of well-defined cords, about 12 on penultimate whorl and in excess of 40 on last adult whorl; weaker, but distinct spirals of similar spacing present on lower half of subsutural ramp. Axial sculpture of low opisthocline riblets confined largely to penultimate and last adult whorls, unevenly spaced; elsewhere, collabral growth lines only, most prominent on subsutural ramp with slightly raised cordlets at uneven intervals, reflecting shape of anal sinus. Last adult whorl evenly convex below subsutural ramp, weakly demarcated from long, evenly tapering siphonal canal, producing slight concavity in apertural view. Aperture elongatepyriform, approximately half of shell length; outer lip thin, unsculptured; inner lip with distinct, rather wide whitish callus; innermost part of columella marked by prominent, elongate burnt-orange vertical stain. Anal sinus wide, moderately deep, broadly u-shaped. Cephalic tentacles broad, muscular, cylindrical, of medium length, with well-developed eyes at their outer base. Rhynchostomal lips thick, with thick-walled, moderately long introvert. Rhynchocoel capacious, internal walls lined in tall, dark red epithelium; oesophagus lined with epithelium of similar appearance. Radula and venom apparatus absent.

\section{Remarks}

Nodothauma magnifica n. gen. n. sp. exhibits some similarities to Abyssobela atoxica Kantor \& Sysoev, 1989, notably in the whorl profile, spiral sculpture, the presence of dark content inside the rhynchocoel, and the absence of a radula and venom apparatus (Kantor \& Sysoev, 1989; Y. Kantor, pers comm.) However, A. atoxica does not possess eyes (Y. Kantor, pers. comm.), whereas in N. magnifica n. gen. the eyes are well-developed and rather large 
411 (see Discussion). Polychaete fragments and foraminiferae have been recovered from the 412 intestine of specimen SAMA D44255.

413

414 Fusobela n. gen.

415 Type species: Fusobela parvioculata n. gen. n. sp.; OD, herein.

416 Etymology: Derived from combination of 'fusus' (Latin = spindle, for its fusiform shell) and 417 'bela' (indicating resemblance with Gymnobela).

418 ZooBank registration: urn:Isid:zoobank.org:act:ED9196C5-E7B8-4FA3-933C-E9BBAA914488 419

420 Diagnosis

421 Shell (Fig. 3B) biconical-fusiform, reddish. Protoconch multispiral. Teleoconch of at least 4

422 rather narrow whorls. Suture moderately impressed. Subsutural ramp wide. Scultpure of

423 irregular spiral cords on whorl periphery and collabral growth lines. Aperture elongate,

424 about half of shell length. Siphonal canal short, not clearly demarcated from shell base. Anal

425 sinus moderately wide, shallowly u-shaped. Rectal gland large, black. Cephalic tentacles

426 closely set, conical; eyes small. Venom apparatus large. Radula (Fig. 6F) of tightly rolled,

427 slender, rather cylindrical hypodermic teeth with no distinct barbs or blades; base rather

428 narrow, short. Ligament rather long, broad.

429

$430 \quad$ Fusobela parvioculata n. sp.

431 (Figs 3B, 5F)

432

433 Material examined 
434 Holotype: Australia, Tasmania, Flat area south of Brians, 1414 m, IN2018_V06_169, (-

$435 \quad 44.239,147.293)$, TMAG E59231.

436

437 Distribution

438 Known only from the type locality.

439

440 Etymology: In reference to the reduced size of its eyes, derived from 'parvus' (Latin = small)

441 and 'oculatus' (Latin = bearing eyes), adjective of feminine gender.

442

ZooBank registration: urn:Isid:zoobank.org:act:54C64B09-3287-4A66-AA3E-AAB0F84BEFF1

444

445 Description. Shell (Fig. 3B) ( $S L=18.2, \mathrm{SW}=8.8$ ) biconical-fusiform, rather thin-walled, semi-

446 translucent. Protoconch multispiral, broadly conical, of 2.7 convex whorls, eroded.

447 Protoconch-teleoconch transition clearly defined, broadly sinuate. Teleoconch of about 4.3

448 whorls with reddish colouration; columellar area dark reddish; suture moderately

449 impressed. Whorls with moderately wide subsutural ramp, straight to slightly convex

450 throughout teleoconch. Lower portion of whorl evenly convex. Teleoconch sculpture of

451 dense collabral growth lines, extending from subsutural ramp to lower portion of whorl;

452 spiral sculpture of cords, more prominent on periphery and with few weaker cords on

453 subsutural ramp. Last adult whorl weakly convex below subsutural ramp, gently tapering

454 into short siphonal canal. Aperture elongate, approximately half of shell length; outer lip

455 very thin, inner lip straight. Anal sinus moderately wide, shallow, u-shaped. 
457 Anatomy (based on female). Osphradium very large; distinct, large, black rectal gland.

458 Cephalic tentacles closely set, thick, conical; eyes small, black. Muscular bulb very large,

459 venom gland long, convoluted, the majority situated ventral to oesophagus. Proboscis long, 460 with folded walls. Radular sac rather large.

461 Radula (Fig. 6F) of hypodermic type, straight to gently curved, tightly rolled, slender, rather 462 cylindrical, attaining $285 \mu \mathrm{m}$ in length; no distinct barb or blade; adapical opening elongate, 463 approaching 1/10 of shaft length; base narrow, comparatively short; external texture 464 medium coarse. Ligament rather long, broad.

466 Remarks

467 Fusobela parvioculata n. gen. n. sp. can be differentiated from other raphitomids by the 468 following combination of characters: a biconical-fusiform, reddish shell with short siphonal canal not clearly demarcated from the shell base; conical, broad cephalic tentacles, and long, cylindrical hypodermic teeth with no distinct barbs or blades.

471 An additional juvenile specimen (AMS C.571736) is here treated as Fusobela cf.

472 parvioculata, due to the identical sculpture of the teleoconch to that of the holotype, and 473 the close genetic relationship. Further study is required to determine whether they ought to 474 be considered truly conspecific, or if they represent a species complex.

476 Aplotoma n. gen.

477 Type species: Aplotoma braevitentaculata n. gen. n. sp.; OD, herein.

478 Etymology: Derived from combination of 'aplous' (ancient Greek = simple, for its featureless 479 shell) and 'toma' (in reference to the family type genus Raphitoma). 
481

482 Diagnosis

483 Shell (Fig. 3C) broadly fusiform, opaque. Teleoconch of at least 5 whitish whorls. Suture

484 impressed. Spire whorls broad, with well-defined shoulder. Subsutural ramp wide, acclivous,

485 with sculpture of thickened u-shaped riblets marking position of anal sinus. Whorl periphery

486 with low, indistinct, widely set folds, intersected by closely spaced, rounded cords. Siphonal

487 canal moderately short. Aperture about half of shell length. Anal sinus wide, u-shaped.

488 Radular teeth (Fig. 6A) of hypodermic type, straight, somewhat loosely rolled, with long

489 dorsal blade; adapical opening subtriangular to ovate, rather short. Base barely wider than

490 basal portion of shaft. Ligament broad.

491

492

Aplotoma braevitentaculata n. sp.

493 (Figs 3C, 6A)

494

495

Material examined

496 Holotype: Australia, VIC, East Gippsland CMR, 2338 m, IN2017_V03_035, (-37.792, 150.382),

497 AMS C.571635.

498

499

Distribution

500 Known from a single locality off East Gippsland, Victoria.

501

502 Etymology: In reference to the comparatively short cephalic tentacles, derived from

503 'braevis' (Latin = short) and 'tentaculatus' (Latin = bearing tentacles), adjective of feminine 504 gender. 
505

506

507

ZooBank registration:

urn:Isid:zoobank.org:act:119007B3-5F12-451E-BF86-C864AEFFB467

Shell (Fig. 3C) $(S L=20.5, \mathrm{SW}=10.9)$ broadly fusiform, rather thin-walled, opaque. Protoconch of at least 2 whorls, eroded. Protoconch-teleoconch transition clearly defined, broadly sinuate. Teleoconch of about 5.3 uniformly whitish whorls, suture impressed. Whorls rather broad, with wide subsutural ramp, straight in early teleoconch whorls and slightly concave on later ones; well-pronounced shoulder situated at approximately mid-height of whorl; lower portion of whorl subcylindrical to cylindrical. Subsutural ramp sculpture of obsolete, low and rounded cords, and evenly spaced, raised arcuate riblets. Supra-peripheral two last cords stronger and more narrowly spaced. Teleoconch axial sculpture of 20 or more rounded opisthocline ribs below subsutural ramp, roughly half to third of interspaces, becoming indistinct toward suture and obsolete toward base of last whorl. Spiral sculpture of regularly spaced cords, about eight densely placed on penultimate whorl, over 30 on last whorl alternate strong and weak, latter becoming indistinct towards whorl base.

Microsculpture of indistinct collabral growth lines. Last adult whorl evenly convex below subsutural ramp, clearly demarcated from straight, moderately short siphonal canal. Aperture elongate, approximately half of shell length; outer lip thin; inner lip whitish, with thin callus, straight. Anal sinus moderately wide, shallow, u-shaped.

Cephalic tentacles very short, conical, very small eyes situated at their outer base. Oesophagus very wide; proboscis short, conical; venom gland rather short.

Radular teeth (Fig. 6A) of hypodermic type, attaining approximately $115 \mu \mathrm{m}$ in length, straight, somewhat loosely rolled. Ventral barb absent, dorsal blade approaching $1 / 3$ of shaft length. Adapical opening subtriangular to elongate-ovate, about $1 / 5-1 / 6$ of shaft 
529 length. Base not swollen, barely wider than widest part of shaft, with medium coarse

530 texture; lateral process present, more or less perpendicular to orientation of shaft. Basal

531 opening large, circular. Ligament rather broad.

532

533 Remarks

534 See Remarks below for comparison with Biconitoma cretosa. Polychaete fragments were 535 recovered from the intestine.

536

537 Biconitoma n. gen.

538 Type species: Biconitoma cretosa n. gen. n. sp.; OD, herein.

539 Etymology: Derived from combination of 'biconicus' (Latin = biconical, for its shell general

540 shape) and 'toma' (in reference to the family type genus Raphitoma Bellardi, 1847).

541 ZooBank registration: urn:Isid:zoobank.org:act:8D2E3C5F-173F-40AB-95A1-BFBA222BEB04

542

543 Diagnosis

544 Shell (Fig. 3D) fusiform-biconical, opaque. Teleoconch of about 5 whitish whorls. Spire

545 whorls broad, with wide subsutural ramp and rounded whorl periphery. Subsutural ramp

546 with 3-4 equally distanced spiral threads, whorl periphery with rounded opisthocline folds

547 and prominent spiral cords throughout height of whorl. Siphonal canal straight, tapering.

548 Aperture elongate, $>50 \%$ of shell length. Anal sinus wide, deeply u-shaped. Cephalic

549 tentacles slightly tapering; eyes absent. Radula (Fig. 6G) of tightly rolled hypodermic teeth

550 with sharp, relatively short blade and triangular adapical opening. Tooth base broad, with

551 weak lateral process and coarse texture. Ligament large, broad. 
553 Biconitoma cretosa n. sp.

554 (Figs 3D, 6G)

555

556 Material examined

557 Holotype: Australia, NSW, off Byron Bay, 2587 m, IN2017_V03_090, (-28.677, 154.203), AMS

$558 \quad$ C.482313.

559 Paratype: Australia, NSW, off Byron Bay, 3825 m, IN2017_V03_099, (-28.371, 154.649), 1

560 wet (AMS C.482288).

561

562 Distribution

563 Known from two adjacent localities off Byron Bay, northern New South Wales.

564

565 Etymology: In reference to the somewhat chalky appearance of the shell, derived from

566 'cretosus' (Latin = chalky), adjective of feminine gender.

567 ZooBank registration: urn:Isid:zoobank.org:act:49AFD1E4-21AD-473C-A983-1504F5AAA623

568 Description. Shell (Fig. 3D) $(S L=24.6, S W=12.9)$ fusiform-biconical, opaque. Protoconch

569 eroded. Teleoconch of about 5 uniformly whitish, chalky whorls; suture impressed. Whorls

570 broad, with wide, flat to lightly concave subsutural ramp and rounded to sub-cylindrical

571 periphery. Shoulder situated slightly below half-height of whorl, severely eroded in early

572 teleoconch whorls. Axial sculpture of 15 or more rounded opisthocline folds below

573 subsutural ramp, roughly half to third width of their interspaces, becoming indistinct toward

574 suture and obsolete toward base of last whorl. Spiral sculpture of fine but distinct threads

575 on subsutural ramp, and rather prominent cords subsequently (totalling about ten on

576 penultimate whorl, $>30$ on last whorl). Microsculpture of indistinct collabral growth lines. 
577 Last adult whorl evenly convex below subsutural ramp, constricted towards stout, tapering

578 siphonal canal. Aperture elongate, a little over half of shell length; outer lip thin,

579 unsculptured. Inner lip whitish, rather straight, gently recurved, with distinct callus. Anal

580 sinus wide, deep, u-shaped.

581 Animal uniform cream. Head broad, blunt. Cephalic tentacles of moderate length, slightly

582 tapering toward blunt tip. Eyes absent. Penis long, slender, cylindrical, with small seminal

583 papilla situated distally; anterior vas deferens long, undulating, visible through epidermis.

584 Introvert rather short; rhynchostomal sphincter thick, muscular. Proboscis very long,

585 narrow, pointed, coiled counterclockwise; venom gland of medium length; muscular bulb

586 elongate, lustrous.

587 Radula (Fig. 6G) of straight, tightly rolled hypodermic teeth attaining $135 \mu \mathrm{m}$ in length; no

588 ventral barb; dorsal blade sharp, approximately $1 / 6$ of length of shaft; adapical opening

589 elongate-triangular, about $1 / 10$ of length of shaft. Base moderately broad, with weak lateral

590 process; exterior of base with coarse texture; basal opening large. Ligament large, broad.

591

592 Remarks

593 This new taxon can be differentiated from other known raphitomids by its biconical shell

594 with distinct spiral cords; the absence of eyes; a long penis with small distal seminal papilla,

595 and comparatively short, tightly rolled, hypodermic teeth with subtriangular adapical

596 openings.

597 In terms of shell morphology, this species can be difficult to differentiate from Aplotoma

598 braevitentaculata (Fig. 3C), despite their difference in radular features (Fig. 6A and 6F) and

599 their demonstrated genetic distinctiveness. However, the latter possesses a distinctly more 
600 convex shell base, a more acutely shouldered whorl profile with narrower subsutural ramp, 601 and its axial sculpture consists of considerably narrower ribs.

602

603 Pagodibelan. gen.

604 Type species: Pagodibela maia n. gen. n. sp.; OD, herein.

605 Etymology: Derived from combination of 'pagoda' (for its pagodiform shell) and 'bela' 606 (indicating resemblance with Gymnobela).

607 ZooBank registration: urn:Isid:zoobank.org:act:94C0A331-C79B-4D25-982A-BE73432D347D 608

609 Diagnosis

610 Shell (Fig. 3E) fusiform-biconical, semi-translucent, with high spire. Protoconch (Fig. 5C)

611 multispiral, cyrthoconoid, with diagonally cancellate sculpture. Teleoconch with at least 6

612 strongly angulated whorls; suture deep. Whorl profile pagodiform, with wide subsutural

613 ramp terminating in prominent carina, below subsutural ramp with raised arcuate riblets

614 and rounded spiral cords. Siphonal canal straight, tapering. Aperture elongate, almost half

615 of shell length. Anal sinus narrow. Cephalic centacles cylindrical; eyes small. Radula (Fig. 6E)

616 of tightly rolled hypodermic teeth with very long dorsal blade and long, narrow adapical

617 opening. Base rather broad, with coarse external texture. Ligament small, short.

618

619 Pagodibela maia n. sp. Criscione

620 (Figs 3E, 5C, 6E)

621

622 Material examined 
623

624

625

626

627

628

629

630

631

632

633

634

635

636

637

638

639

640

641

642

643

644

645

Holotype: Australia, Coral Sea CMR, 1013 m, IN2017_V03_121, (-23.587, 154.194), AMS

C.571678,

\section{Distribution}

Known only from the type locality.

ZooBank registration: urn:Isid:zoobank.org:act:30D02181-94B6-45D7-9275-CEA1845F3DE6

Etymology: In honour of my adorable little explorer Maia Criscione, in recognition of the love she has always expressed for the natural world, noun in apposition.

Description. Shell (Fig. 3E) (SL=19.9, SW=9.5) fusiform-biconical, thin-walled, semi-

translucent. Protoconch (Fig. 5C) orange, multispiral, broadly conical, of 2.5 gently convex to indistinctly shouldered diagonally cancellate whorls. Protoconch-teleoconch transition clearly defined, broadly sinuate. Teleoconch of 6.2 white, strongly angulated whorls; suture deeply impressed. First teleoconch whorl convex to indistinctly shouldered, succeeding whorls pagodiform, with wide, straight or slightly concave subsutural ramp concluded by gemmate carina situated about mid-height of whorl. Whorl base narrowing clearly towards lower suture. Subsutural ramp sculpture of low and rounded cords, and evenly spaced, raised arcuate riblets producing somewhat reticulate pattern. Supra-peripheral two last cords stronger and more narrowly spaced. At whorl base, regularly spaced, alternate strong and weak cords, somewhat gemmate due to weak nodules at intersections of cords with dense collabral riblets. Last adult whorl with almost triangular base, shortly constricted to and clearly demarcated from straight, tapering siphonal canal. Aperture elongate, nearly 
646 half of shell length; outer lip thin; inner lip whitish, with thin callus, straight. Anal sinus 647 narrow.

648 Head wide, cephalic tentacles cylindrical; small black eyes situated at their bases. Penis 649 small, simple. Proboscis elongate, conical, not large; venom gland short; muscular bulb 650 large.

651 Radular teeth (Fig. 6E) of hypodermic type, attaining about $175 \mu \mathrm{m}$ in length, relatively 652 straight to slightly curved, tightly rolled; barbs absent; dorsal blade extremely long, 653 approaching half of shaft length; adapical opening very narrow and elongate, approximately $6541 / 3$ of shaft length; base rather broad, external texture coarse, consisting of dense network 655 of diagonal ridges, becoming obsolete toward lateral margins; lateral process very weak; 656 basal opening large, subcircular. Ligament small, short.

657

658 Remarks

659 This taxon can be differentiated from other raphitomids by its pagodiform shell with a 660 gemmate carina, sculpture of equally spaced fine spiral cords and a radula with hypodermic 661 teeth bearing extremely long dorsal blade and adapical openings.

662

663 Austrobela n. gen.

664 Type species: Austrobela rufa n. gen. n. sp.; OD, herein.

665 Etymology: Derived from combination of 'auster' (Latin = south; for its discovery in the 666 Southern Hemisphere) and 'bela' (indicating resemblance with Gymnobela).

667 ZooBank registration: urn:Isid:zoobank.org:act:COAFB30C-6D3C-42EB-98F1-624BF9E75CC3 668 669 Diagnosis 
670 Shell (Fig. 3F) fusiform. Protoconch (Fig. 5E) multispiral, orange. Teleoconch whorls clearly

671 shouldered, with subcylindrical lower portion. Scultpure of axial riblets below subsutural

672 ramp; spiral sculpture of fine, sometimes flattened cords or shallow grooves; misrosculpture

673 of growth lines. Aperture elongate, large, about half of shell length. Siphonal canal long,

674 straight; columella straight. Sinus wide, L-shaped. Cephalic tentacles muscular,

675 subcylindrical; eyes large. Rhynchodeal introvert rather thin-walled, densely folded. Venom

676 apparatus extremely large, occupying majority of rhynchocoel. Radula (Fig. 6D) of

677 hypodermic teeth with two large, sharp distal barbs; lower portion of shaft somewhat

678 inflated; base broad; ligament thick.

679

680 Austrobela rufa n. sp.

681 (Figs 3F, 5E, 6D)

682

683 Material examined

684 Holotype: Australia, GAB, 965 m, IN2015_C02_131, (-35.153, 134.109), AMS C.571709.

685 Paratypes:

686 Australia, GAB, 978 m, IN2015_C02_382, (-33.516, 130.265), 1 wet (AMS C.571680); 1029 m, 687 IN2015_C01_110, (-34.629, 132.356), 1 wet (AMS C.483817); 1016 m, IN2015_C01_117, ($68834.674,132.479), 1$ wet (AMS C.571681); 994 m, IN2015_C01_114, (-34.705, 132.531), 1 wet 689 (AMS C.571679); 1350 m, IN2015_C01_108, (-34.738, 131.841), 2 wet (SAMA D44253); 2 690 wet (AMS C.483801); 1 wet (AMS C.483802); 2 wet (AMS C.571668); 1015 m, 691 IN2015_C02_167, (-34.823, 132.692), 1 wet (AMS C.532677); 1509 m, IN2015_C02_134, (692 35.345, 134.045), 1 wet (AMS C.532691); 1 wet (AMS C.571699). Australia, Tasmania, St 
693

694

695

696

697

698

699

700

701

702

703

704

705

706

707

708

709

710

711

712

713

714

715

716

Helens flat, 1127 m, IN2018_V06_184, (-41.209, 148.797), 1 wet (AMS C.574588); 1 wet (AMS C.271201).

\section{Distribution}

Known from the Great Australian Bight, northern Tasmania and the southern coast of New South Wales.

Etymology: In reference to the colouration of its shell, derived from 'rufus' (Latin = red), adjective of feminine gender.

ZooBank registration: urn:Isid:zoobank.org:act:9212F7D7-D734-49A7-94AB-B24011C9BFF9

Description. Shell (Fig. 3F) (SL=35.4, SW=14.6) thin-walled, fusiform, semi-translucent to opaque. Protoconch (Fig. 5E) (based on paratype AMS C.571681) orange, cyrthoconoid, multispiral, with 4.5 whorls, first whorl with punctate sculpture (Fig. 5E), remaining whorls with fine, evenly distanced arcuate riblets (about 35 on last whorl). Protoconch-teleoconch transition sharply delineated, broadly sinuate. Teleoconch of about six whorls with broad, slightly concave subsutural ramp. Whorl lower portion with axial sculpture of strong, rather sharp opisthocline ribs, well-pronounced at shoulder of two earliest and last teleoconch whorls; whorls subcylindrical below shoulder. Third and penultimate whorls without pronounced axials. Microsculpture of dense growth lines on subsutural ramp and very fine spiral cords on whorl lower portion. Last adult whorl with about 16 axials, vanishing shortly below shoulder. Shell base evenly convex, clearly demarcated from long, slender tapering siphonal canal. Aperture elongate, about half of length of shell, rounded below shoulder and 
717

718

narrowing toward siphonal canal. Outer lip thin, inner lip smooth, with narrow callus on long, rather straight columella bearing vertical orange stain. Sinus wide, moderately deep, Lshaped. Shell surface glossy, early teleoconch whorls pale orange or cream, subsequent whorls of orange colour.

Anatomy (based on AMS C.27120, female, except penial characters based on AMS C.571679, male). Animal uniform whitish/cream. Cephalic tentacles large, muscular, long, subcylindrical; large eyes on outer lower base of tentacles. Rhynchostome subcircular, lined with numerous epithelial cells; very large, thin-walled introvert with numerous longitudinal folds. Oviduct large; intestine lightly curved along length of oviduct, posterior to it. Penis rather large, coiling clockwise, simple. Rectal gland greenish, filamentous/bristly in appearance, parallel to anterior intestine.

Rhynchocoel with dark red content. Venom apparatus extremely large, occupying most of rhynchoocoel; proboscis large, elongate; radular sac extremely large; venom gland very large, thick, whitish, very long and convoluted; muscular bulb lustrous, yellow, extremely large, elongate, with indentation posteriorly where pressed against oesophagus.

Radula (Fig. 6D) (based on AMS C.571679; AMS C.571709; AMS C.574588) of straight to gently curved, somewhat loosely rolled hypodermic teeth of up to $350 \mu \mathrm{m}$ in length; lower half of shaft rather cylindrical, somewhat inflated, distal half weakly tapering toward prominent dorsal and ventral distal barbs, of which ventral barb more distal from tip; dorsal barb sharper than ventral barb. Adapical opening elongate, narrow, boundaries not clearly defined due to loosely overlapping tooth margins, up to $1 / 5$ of shaft length. Basal third of shaft with weakly rugose texture. Base rather broad, with medium coarse texture on exterior. Basal opening large. Ligament about half width of base, solid, thick. 
741 Remarks

742 This species can be differentiated from other raphitomids by the following combination of

743 characters: a glossy shell with weakly developed sculpture, clearly pronounced, but rounded

744 shoulder, and yellowish orange to reddish brown colouration; a hypodermic radula with two

745 large, sharply hooked barbs; an extremely large venom apparatus occupying almost the

746 entire rhynchocoel; a thin-walled, strongly folded introvert and the presence of well-

747 developed, large eyes.

748 Although DNA sequence data for the holotype was not included in the analysis of Figure 2, a

749 COI sequence was generated and is available on Genbank (AN MN983272).

750 This is a quite variable taxon based on shell morphology, with some specimens examined

751 exhibiting shells with little to no distinct sculpture.

752 Based on its shell morphology, this new taxon bears considerable similarity to the northeast Atlantic Gymnobela fulvotincta (Dautzenberg \& Fischer, 1996). However, when compared to the holotype of the latter, the following characters observed in G. fulvocincta distinguishes this species from $A$. rufa n. gen. n. sp.: more prominent axial ribs, producing a more angulate whorl profile; a shoulder situated lower on adult whorls; a less cylindrical whorl periphery, and a columella that is distinctly curved when observed in apertural view as opposed to the straight columella in A. rufa n. gen. n. sp. In terms of radular morphology, the hypodermic tooth figured in Bouchet \& Warén (1980, fig. 24) shows barbs that appear distinctly less prominent in G. fulvotincta, and a shaft that tapers gradually as opposed to the somewhat inflated lower half of the shaft in A. rufa n. gen. n. sp. (Fig. 6D). When compared to the superficially similar Gymnobela yoshidai (Kuroda \& Habe, 1961), A. rufa n. gen. n. sp. bears a significantly broader shell and a more sharply inclined subsutural ramp

764 (Sysoev \& Bouchet, 2001, figs 134-144). 
766 Glaciotomella n. gen.

767 Type species: Glaciotomella investigator n. gen. n. sp.; OD, herein.

768 Etymology: Derived from combination of 'glacius' (Latin = ice, for the glossy, icy-like surface

769 of its shell) and 'tomella' (indicating resemblance with Pleurotomella).

770 ZooBank registration: urn:Isid:zoobank.org:act:6FE3648B-B095-4996-B90E-C4DF4640961A

771

772 Diagnosis

773 Shell (Fig. 3G) with cyrtoconoid spire, chalky, semi-translucent to opaque. Teleoconch of

774 about 5 whitish whorls; whorl profile with weakly pronounced subsutural ramp, broadly

775 convex below. Suture deep. Scultpure below subsutural ramp of orthicline axial ribs and

776 spiral sculpture of intermittent weak and strong cords (most prominent on immature

777 whorls). Siphonal canal long, clearly differentiated from last adult whorl. Aperture broadly

778 pyriform, about half of shell length. Anal sinus moderately deep, J-shaped. Cephalic

779 tentacles small; eyes minute. Rhynchostome and rhynchostomal sphincter extremely large;

780 rhynchocoel short. Radula of long, straight, cylindrical hypodermic teeth with no distinct

781 barbs or blades.

782

783 Glaciotomella investigator n. gen. n. sp.

$784 \quad$ (Fig. 3G)

785

786 Material examined

787 Holotype: Australia, New South Wales, Hunter CMR, 2595 m, IN2017_V03_070, (-32.575, 
790 Distribution

791 Known only from the type locality.

792

793 Etymology. In reference to the Australian Government's RV Investigator, on which the 794 expedition was conducted that allowed for this species (and many other species described 795 herein) to be collected, noun in apposition.

796

797 ZooBank registration: urn:Isid:zoobank.org:act:0B100DF6-9DEB-402B-A382-2964754D285B 798

Description. Shell (Fig. 3G) (SL=20.8, SW=10) with cyrthoconoid spire, relatively thin-walled, 800 chalky, semi-translucent to opaque. Protoconch largely eroded. Teleoconch of 5 whitish 801 whorls with slightly concave subsutural ramp, evenly and broadly convex below. Suture 802 deep. Subsutural ramp sculpture of fine, rather regularly set axial riblets. Teleoconch sculpture below subsutural ramp of orthocline axial ribs, extending from subsutural ramp to 804 suture, rather prominent on early teleoconch whorls, progressively weakening toward last whorl (about 18 on penultimate whorl, $>20$ on last whorl); numerous weak, densely set, collabral growth lines between axial ribs; spiral sculpture of regularly spaced cords with finer cordlets in their interspaces, more differentiable on early teleoconch whorls, resulting in

808 distinctly cancellate early- to mid teleoconch whorls, and with a finer meshwork of axial and 809 spiral elements on last adult whorl. Last adult whorl broadly convex below subsutural ramp, 810 abruptly constricted to long siphonal canal. Boundary between last whorl and siphonal canal 811 on left side (in apertural view) deeply concave, with siphonal canal distinctly convex.

812 Aperture broadly pyriform, about half of shell length; outer lip very thin; inner lip with thin 
813 glossy whitish callus. Columella rather straight in apertural view, distinctly convex in lateral

814 view. Anal sinus moderately deep, J-shaped.

815 Mantle of single studied specimen stained with crimson, originating from distinct, well-

816 developed rectal gland (although this staining is certainly a post-mortem feature, it may be

817 useful to differentiate the species from conchologically similar species in other lineages).

818 Head with small cephalic tentacles situated on either side of rhynchostome, with extremely

819 small eyes situated at their outer base. Rhynchostome and rhynchostomal sphincter

820 extremely large; rhynchocoel short, with proboscis occupying most of its length. Proboscis

821 with strongly folded walls; venom gland long, convoluted; muscular bulb large.

822 Radula of hypodermic teeth attaining $310 \mu \mathrm{m}$ in length, rather straight, cylindrical. No

823 distinct barb or blade.

824

Remarks

826 This new taxon can be differentiated from other raphitomids by the following combination

827 of characters: a broadly fusiform shell, with strongly convex whorl profile, cancellate

828 sculpture on early- to mid- teleoconch whorls, and a long, straight columella with a curved

829 siphonal canal in lateral view (Fig. 3G); an extremely large rhynchostome, and long, rather

830 straight and cylindrical hypodermic teeth with no distinct barb or blade.

831 Glaciotomella investigator $\mathrm{n} . \mathrm{sp}$. is similar to Pleurotomella (specifically, compared here to

832 type species P. packardii, Verrill, 1872, and not to Pleurotomella in the broad sense), in that

833 both taxa possess a shell with prominent sculpture, strongly convex whorls with an

834 impressed suture, and a rather long siphonal canal. However, G. investigator differs from

835 the latter in having a distinctly broader, more convex and less shouldered whorl profile, and

836 a comparatively straight columella (which in $P$. packardii exhibits a prominent left-turning 
837 curve toward the anterior of the siphonal canal). Furthermore, our molecular results suggest 838 that Glaciotomella and Pleurotomella are in fact not closely related within the Raphitomidae 839 (Fig. 2). The radula of this species is not figured due to poor preservation state. 840

841 Austrotheta n. gen.

842 Type species: Austrotheta crassidentata n. gen. n. sp.; OD, herein.

843 Etymology: Derived from combination of 'auster' (Latin = south; for its discovery in the 844 Southern Hemisphere) and 'theta' (indicating resemblance with Theta).

845 ZooBank registration:

846 urn:Isid:zoobank.org:act:1FCE9160-3FA0-44F9-89DE-46A6FA46ACA7

Diagnosis

Shell (Fig. 3H) fusiform, semi-translucent to opaque. Protoconch multispiral; sculpture of arcuate cordlets on upper portion of whorls and diagonally cancellate below. Teleoconch with distinctly shouldered to rounded whorls, bearing sharp opisthocline axial ribs in early

852 to median whorls; last whorl evenly convex below narrow subsutural ramp, with undulating striae throughout its height. Siphonal canal long and straight. Aperture wide, pyriform, 854 about half of shell length. Anal sinus rather shallow, u-shaped. Eyes minute. Radula (Fig. 6H) of very thick, cylindrical hypodermic teeth, bearing two weak distal barbs and with very

856 short adapical opening. Base very broad, with extremely coarse external sculpture. Ligament 857 very large.

859 Austrotheta crassidentata n. gen. n. sp.

860 (Figs 3H, 6H) 
861

862

Material examined

863

Holotype: Australia, Tasmania, Freycinet Commonwealth Marine Reserve, 2820 m,

IN2017_V03_004, (-41.731, 149.12), AMS C.519302.

865

866

Distribution

867

Known only from the type locality.

868

Etymology: In reference to its thick hypodermic tooth, derived from 'crassus' (Latin = thick)

and 'dentatus' (Latin = bearing theet), adjective of feminine gender.

870

ZooBank registration:

871

urn:Isid:zoobank.org:act:4EF95055-B0D2-4151-89B1-762BD62DF8DE

872

Description. Shell (Fig. 3H) $(S L=20.9, \mathrm{SW}=9.6)$ fusiform, rather thin-walled, semi-translucent

to opaque. Protoconch orange, multispiral (at least 2.5 whorls), with arcuate cordlets on adapical half to two-thirds of whorl, with diagonally cancellate sculpture below. Teleoconch of 4.4 whorls; subsutural ramp distinctly concave in early whorls, in more mature whorls less distinct and with less marked concavity. Whorl profile with prominent shoulder on early teleoconch whorls, situated at adapical third of whorl; in penultimate whorl more rounded, in last adult whorl indistinct; whorl periphery nearly cylindrical in early teleconch, more convex in mature whorls. Early teleoconch whorls with about 12 sharp, weakly opisthocline axials, vanishing well above suture, indistinct in later whorls. Spiral sculpture of dense, slightly undulating striae pronounced throughout last whorl. Microsculpture of collabral growth lines, forming distinct, raised cordlets on subsutural ramp in early whorls, weaker in more mature whorls. Last adult whorl evenly convex below subsutural ramp, with long, 
slender siphonal canal. Aperture wide, pyriform, about half of shell length. Inner lip with

whitish callus, rather straight. Outer lip thin, unsculptured. Anal sinus rather shallow, weakly

887

u-shaped.

Head wide, eyes very small. Muscular bulb extremely large; proboscis short, wide; radular sac thin, bearing few teeth.

890

Radula (Fig. 6H) of very thick, straight cylindrical hypodermic teeth exceeding $175 \mu \mathrm{m}$ in

891 length; two weak distal, lateral barbs; adapical opening very short, lateral (i.e., orientation

of barbs and adapical opening offset to point of overlap between margins near base); base very broad, inflated, with extremely coarse external sculpture (Fig. 6H); ligament very large.

Remarks

896

Austrotheta crassidentata n. gen. n. sp. differs from other raphitomids in the following

combined characters: a fusiform shell with sharp, weakly opisthocline axials on early

teleoconch whorls and weakly sculptured late teleoconch whorls; slender siphonal canal;

900 orientated adapical opening, as well as a broad base with extremely coarse external

901 sculpture.

902 Based on its shell morphology, A. crassidentata n. gen. n. sp. resembles Gymnobela yoshidai

903 (Kuroda \& Habe, 1961), in which strongly shouldered subcylindrical early teleoconch whorls

904 with sharp ribs are succeeded by evenly convex and finely striate whorls. However, the

905 latter species has a narrower shell with a pointed spire, and a less convex, more elongated

906 shell base, as well as a yellowish staining of the shell. A similar change in the whorl outline

907 and sculptural pattern can be observed in Spergo fusiformis (based on the type series

908 illustrated by Sysoev \& Bouchet, 2001), although the latter can be readily differentiated 
909 from A. crassidentata n. gen. n. sp. by its larger size and narrower, rather lanceolate

910 aperture. A.crassidentata n. gen. n. sp. also shows some resemblance to Austrobela rufa n.

911 gen. n. sp., but can be readily differentiated by its diagonally cancellate protoconch, sharp

912 axial ribs, a more convex shell base, and its whitish shell. When compared to T. lyronuclea, it

913 differs in its more elongate shell and in its diagonally cancellate protoconch (which is

914 arcuate in both $A$. rufa and T. lyronuclea).

915

916

917 Gladiobela n. gen.

918 Type species: Gladiobela angulata n. gen. n. sp.; OD, herein.

919

920 Etymology: Derived from combination of 'gladius' (Latin = sword; for the long blade of its

921 hypodermic tooth) and 'bela' (indicating resemblance with Gymnobela).

922

923 Diagnosis

924 Shell (Fig. 4A) fusiform-biconical, semi-translucent. Protoconch multispiral, lower whorl

925 portion diagonally cancellate, upper portion with arcuate sculpture only. Teleoconch with

926 broad whorls with shoulder situated at mid-height of whorl. Anal sinus very wide, u-shaped.

927 Animal with long, cylindrical tentacles; eyes very small. Radula (Fig. 6B) of hypodermic type,

928 awl-shaped, with very long adapical opening; dorsal blade extremely long; base broad,

929 angular.

930

931 ZooBank registration:

932 urn:Isid:zoobank.org:act:1FD74C2F-24EC-4FA6-B62F-02C380F9CAC9 
934 Gladiobela angulata n. gen. n. sp.

935 (Figs 4A, 6B)

936

937 Material examined:

938 Holotype: Australia, New South Wales, Hunter CMR, 2595 m, IN2017_V03_070, (-32.575, 939 153.162), 1 wet (AMS C.571651).

940 Paratypes: Australia, GAB, 3350 m, IN2017_C01_197, (-34.452, 129.492), 1 wet (AMS

941 C.571737); 1 wet (AMS C.571735); 1 wet (AMS C.571738); 1 wet (AMS C.572166); 1 wet

942 (AMS C.572167); 1 wet (AMS C.572168); 1 wet (SAMA D49343); 3540 m, IN2017_C01_198,

$943(-34.574,129.572), 1$ wet (SAMA D49341); 1 wet (SAMA D67750); 1 wet (SAMA D67751);

9443807 m, IN2017_C01_192, (-34.589, 129.418).

945

946 Distribution

947 Known from the Great Australian Bight and one locality off the Hunter Commonwealth 948 Marine Reserve, New South Wales.

949

950 Etymology: In reference to the distinct angulation at its whorl periphery, derived from

951 'angulata' (Latin = with angles), adjective of feminine gender.

952

953 ZooBank registration: urn:Isid:zoobank.org:act:F40216C9-F620-49A9-B91E-A91F118F7DF8

954 Description. Shell (Fig. 4A) $(S L=18.8, \mathrm{SW}=10.2)$ broadly fusiform-biconical, rather thin-

955 walled, semi-translucent. Protoconch (based on SAMA D49341) orange, first whorl(s)

956 strongly eroded, subsequent 1.5 whorls with diagonally cancellate sculpture on abapical 
957

958

959

960

961

962

963

964

965

966

967

968

969

970

971

972

973

974

975

976

977

978

979

980 third, above with arcuate sculpture only. Clear protoconch-teleoconch boundary marked by deep sinus. Teleoconch of about 4.5 uniformly honey-coloured whorls, suture impressed.

Whorls broad, with very wide, slightly concave subsutural ramp; well-defined, prominent shoulder situated at approximately mid-height to just below mid-height of whorl. Axial sculpture of growth lines only, on early whorls forming slightly raised, densely set riblets.

Spiral sculpture of densely set, evenly spaced sub-peripheral cords (about 8 on penultimate whorl, $>30$ on last whorl), few very weak cords present immediately above shoulder. Last adult whorl with slight concavity immediately below subsutural ramp, below - evenly convex, clearly demarcated from slightly tapering, long siphonal canal. Aperture elongate, approximately half of shell length; outer lip thin, unsculptured. Inner lip whitish, gently recurved. No distinct callus. Anal sinus very wide, moderately deep, u-shaped.

Anatomy (based on AMS C.571737 and AMS C.571651): Animal semi-translucent whitish.

Cephalic tentacles very long, narrow, cylindrical, with extremely small eyes situated at their lower outer base. Penis rather long, narrow. Muscular bulb very long, colourless; proboscis long.

Radula (Fig. 6B) of straight to gently curved hypodermic teeth exceeding $175 \mu \mathrm{m}$ in length; no ventral barb; dorsal blade sharp, extremely long, approximately half of shaft length; adapical opening very elongate, rather narrow, ranging between $1 / 4-1 / 2$ of shaft length. Base rather broad, with distinct crescentic, slightly excavated shelf more or less perpendicular to orientation of shaft (Fig. 6B); large dorsal platform extending posteriorly, with numerous, densely arranged folds on inner surface; exterior of base with comparatively fine texture; basal opening large. Ligament broad.

Remarks 
981 This new taxon can be differentiated from other raphitomids by its rather broad shell with a 982 well-defined carina and a cylindrical whorl periphery with regularly spaced spiral cords, and 983 by its hypodermic radular teeth with a very long dorsal blade extending approximately half 984 the length of the shaft, and a prominent base forming a crescent-shaped, indented 985 platform. 986

987 Pueridaphne n. gen.

988 Type species: Pueridaphne cirrisulcata n. gen. n. sp.; OD, herein.

989 Etymology: Derived from combination of 'puer' (Latin = child; for the similarity of its 990 teleoconch to that of the larval shell sculpture) and 'daphne' (indicating resemblance with 991 some species of Daphnella Hinds, 1844).

992 ZooBank: urn:Isid:zoobank.org:act:00258E64-8241-4207-9744-65B4BFE2C68C 993

994 Diagnosis

995 Shell (Fig. 4B) fusiform, opaque. Protoconch (Fig. 5D) multispiral, of 4.5 whorls of which first 996 whorl exhibits punctate sculpture; subsequent whorls diagonally cancellate. Teleoconch of 997 at least 4.5 uniformly white whorls. Suture impressed. Teleoconch whorls with wide 998 subsutural ramp and well-defined shoulder in immature whorls, lower whorl portion and 999 shell base with fine cancellate sculpture. Siphonal canal long, straight. Anal sinus wide, 1000 deeply u-shaped. Animal reddish brown. Cephalic tentacles (Fig. S4A) very long, cylindrical, 1001 exhibiting longitudinal groove throughout; eyes very small. Venom apparatus (Fig. S4B) 1002 large. Radula (Fig. 6C) of straight, tightly rolled hypodermic teeth with sharp, very long blade 1003 and long adapical opening. Base broad, with lateral process and extremely coarse external 1004 texture. Ligament broad. 
1005

1006 Pueridaphne cirrisulcata n. gen. n. sp.

1007 (Figs 4B, 5D, 6C, 9)

1008

1009 Material examined:

1010 Holotype: Australia, GAB, 3350 m, IN2017_C01_197, (-34.452, 129.492), AMS C.572165.

1011 Paratypes: Australia, New South Wales, Hunter CMR, 4031 m, IN2017_V03_079, (-32.131,

1012 152.527), 1 wet (AMS C.563160); Jervis CMR, 2667 m, IN2017_V03_055, (-35.335, 151.259),

10131 wet (AMS C.563103); VIC, East Gippsland CMR, 3850 m, IN2017_V03_032, (-38.479,

1014 150.185), 1 wet (AMS C.571609); GAB, 3350 m, IN2017_C01_197, (-34.452, 129.492), 1 wet

1015 (AMS C.571631); 3540 m, IN2017_C01_198, (-34.574, 129.572), 1 wet (SAMA D49340a).

1016

1017 Distribution

1018 Known to occur from the Great Australian Bight, via East Gippsland, Victoria, northward 1019 along the southeast Australian coast to the Hunter Commonwealth Marine Reserve, New 1020 South Wales.

1021

1022 Etymology: In reference to the groove present along the cephalic tentacles, derived from

1023 'cirrus' (Latin = tentacle) and 'sulcatus' (Latin = bearing a groove), adjective of feminine 1024 gender.

1025

1026 ZooBank registration: urn:Isid:zoobank.org:act:OF0DD864-FF79-4C78-8A06-F99431B19039 1027 
1028 Description. Shell (Fig. 4B) $(S L=15, S W=7.4)$ fusiform, rather thin-walled, opaque. Protoconch 1029 (based on paratype AMS C.563103) orange, broadly conical, multispiral, with 4.5 whorls, 1030 first whorl with punctate sculpture, subsequent whorls diagonally cancellate (Fig. 5D). 1031 Protoconch-teleoconch transition clearly defined, broadly sinuate. Teleoconch of 4.6 1032 uniformly whitish whorls, suture impressed. Whorls rather broad, with wide subsutural 1033 ramp, steep in early teleoconch whorls and progressively more concave in later whorls; 1034 well-pronounced shoulder situated at approximately mid-height of whorl. Subsutural ramp 1035 sculpture of raised, dense growth lines. Lower whorl portion with axial sculpture of 1036 numerous (> 100 on last whorl), dense, raised growth lines, intersecting rounded, evenly 1037 spaced (>20 on last whorl) spiral cords to form distinctly diagonally cancellate pattern; sculpture weaker on last whorl. Last adult whorl evenly convex below subsutural ramp; siphonal canal slender, moderately long, slightly curved. Aperture elongate, approximately half of shell length; outer lip thin, unsculptured. Inner lip whitish, gently recurved toward 1041 left with spiral sculpture extending uninterrupted from base, with very thin callus. Anal sinus wide, deep, u-shaped.

Anatomy (based on SAMA D49340a; AMS C.572165; AMS C.571609). Animal reddish brown, with epidermis of very fine textile-like appearance; head short, rather blunt. Penis large, very long, coiled clockwise, subcylindrical, tip blunt (Fig. S4A). Cephalic tentacles very long, cylindrical, bearing densely set latitudinal folds; distinct longitudinal groove present along 1047 their full length (Fig. S4A). Eyes very small, situated at outer lower base of cephalic tentacles. Prostate (Fig. S4A) gland large, yellowish, clearly visible beneath thin epidermis; 1049 anterior vas deferens undulating.

1050 Introvert large, thick-walled, cup-shaped with expanding rim, whitish; rhynchostomal 1051 sphincter bluish grey, encircling introvert periphery, surrounded on both sides by dense 
1052

1053 clockwise in rhyncocoel, outer walls bearing dense, very strong latitudinal folds (Fig. S4B);

1054 radular sac large; venom gland long and convoluted, colourless, situated posterior right of

1055 proboscis; muscular bulb ovate, lustrous pink, with micro-fibrous surface (Fig. S4B).

1056 Radula (Fig. 6C) (based on SAMA D49340a; AMS C.572165; AMS C.571609) of hypodermic

1057 teeth, straight, tightly rolled, attaining $150 \mu \mathrm{m}$ in length, rather broad; slight constriction at

1058 approximately lower-third mark of shaft; no ventral barb; dorsal blade sharp, extending

1059 about $1 / 3$ of shaft length; adapical opening elongate-ovate, approximately $1 / 5$ to $1 / 6$ shaft

1060 length, seen as marked indentation in lateral profile; base broad, angular, with distinct

1061 lateral process; basal texture extremely coarse, with dense network of weakly triangular to

1062 subcircular tubercles, larger on base proper than (immediate) basal portion of shaft; basal

1063 opening broad. Ligament broad.

1064

1065 Remarks

1066 This new taxon can readily be distinguished from other raphitomids by the following

1067 combination of characters: a densely cancellate teleoconch; dark red pigmentation of the

1068 external animal; very long, strongly folded cephalic tentacles with a longitudinal groove or

1069 furrow extending across their full length; an extremely long, strongly folded proboscis;

1070 radular teeth with a long blade, a slight constriction of the shaft at its abapical third, and an

1071 extremely coarse texture on the base exterior.

1072

1073 Globodaphne n. gen.

1074 Type species: Globodaphne pomum n. gen. n. sp.; OD, herein. 
1086

1087

1088

1089

1090

1091

1092

1093

1094

1095

1096

1097

1098

Etymology: Derived from combination of 'globus' (Latin = globe, for its sub-globose shell) and 'daphne' (indicating resemblance to Xanthodaphne).

ZooBank registration: urn:Isid:zoobank.org:act:369D1B2A-EDCA-48E2-83AD-C6215BD46D28

\section{Diagnosis}

Shell (Fig. 4C) sub-globose, thin-walled, semi-translucent. Protoconch (Fig. 5B) multispiral, with dense diagonally cancellate sculpture. Teleoconch of few, pale whorls. Suture impressed. Whorl profile very broad, strongly convex. Sculpture throughout whorl of dense, weakly arcuate riblets and dense, irregularly set spiral cordlets. Siphonal canal straight, short. Aperture wide, ovate, about $2 / 3$ of shell length. Anal sinus very shallow. Cephalic tentacles long, cylindrical; eyes extremely small. Venom apparatus and radula absent.

Globodaphne pomum n. gen. n. sp.

(Figs 4C, 5B)

Material examined

Holotype: Australia, New South Wales, Hunter CMR, 2595 m, IN2017_V03_070, (-32.575, 153.162), AMS C.482283.

Distribution

Known only from the type locality.

Etymology: In reference to the somewhat globose shape of its shell, derived from 'pomum' (Latin = apple), noun in apposition . 
1099

1100

1101

1102

1103

1104

1105

1106

1107

1108

1109

1110

1111

1112

1113

1114

1115

1116

1117

1118

1119

1120

1121

1122

ZooBank registration: urn:Isid:zoobank.org:act:F590311C-2E22-41BA-B3E1-558F746AA2BD

Description. Shell (Fig. 4C) (SL=14.1, SW=10) sub-globose, rather thin-walled, semi-

translucent. Protoconch (Fig. 5B) multispiral, broadly cyrthoconoid, orange, of about 3

convex whorls; protoconch sculpture of numerous (about 60 on last whorl) thin opisthocline riblets, about half width of interspaces, and (9 on last whorl) weak spiral cordlets, becoming more conspicuous toward transition to teleoconch. Protoconch-teleoconch transition rather gradual, demarcated by colour transition. Teleoconch of about 2.7 pale orange whorls,

suture impressed. Whorls very broad, with wide, poorly defined subsutural ramp. Lower

portion of whorl evenly convex. Teleoconch sculpture of dense, thin, regularly spaced,

moderately arcuate riblets (50 on last whorl) and dense, low, irregularly spaced cordlets

(about 90 on last whorl). Riblets extending to suture on first 2 whorls and becoming

somewhat inconspicuous towards base of last adult whorl. Microsculpture of very dense,

barely detectable collabral growth lines. Last adult whorl evenly convex below subsutural

ramp, clearly demarcated from straight, short siphonal canal. Aperture wide, ovate,

approximately two-thirds of shell length; outer lip very thin, inner lip cream-orange, with thin callus, straight. Anal sinus very shallow.

Cephalic tentacles long, cylindrical; eyes extremely small. Very large introvert, occupying most of rynchocoel volume. Venom apparatus and radula absent.

Remarks

This taxon exhibits some superficial resemblance in shell morphology to T. cuprosa $\mathrm{n}$. gen. $\mathrm{n}$. sp., described below, which also possesses a sub-globose shell. In terms of differences in shell morphology, G. pomum n. gen. n. sp. can be distinguished from the latter by its less 
1123 steep subsutural whorl portion, deeper suture, and more delicate spiral sculpture. When 1124 compared to Lusitanops F. Nordsieck, 1968 [type species L. lusitanicus (Sykes, 1906)] and 1125 Xanthodaphne (type species X. membranacea), G. pomum exhibits a distinctly more globose 1126 shell. Additionally, it can readily be differentiated from Lusitanops by its clearly delineated 1127 siphonal canal, and from Xanthodaphne by its comparatively shallow anal sinus.

1129 Trochodaphne n. gen.

1130 Type species: Trochodaphne cuprosa n. gen. n. sp.; OD, herein.

1131 Etymology: Derived from a combination of 'trochus' (Latin = spinning top, for its shell shape) 1132 and 'daphne' (indicating resemblance with Xanthodaphne).

1133 GenBank registration: urn:Isid:zoobank.org:act:7C58D631-5865-4B7A-913C-0CBAFC72522A 1134

Diagnosis

Shell (Fig. 4D) sub-globose, semi-translucent. Protoconch (Fig. 5A) multispiral, with

diagonally cancellate sculpture. Teleoconch of few copper-hued whorls. Suture moderately 1138 impressed. Whorl profile broad, convex, no distinct subsutural ramp. Teleoconch sculpture 1139 of alternating strong and weak spiral cords. Aperture wide, ovate, $>2 / 3$ of shell length. Anal 1140 sinus indistinct.

1142 Trochodaphne cuprosa n. gen. n. sp.

1143 (Figs 4D, 5A)

1145 Material examined 
1146

1147

1148

1149

1150

1151

1152

1153

1154

1155

1156

1157

1158

1159

1160

1161

1162

1163

1164

1165

1166

1167

1168

1169

Holotype: Australia, New South Wales, Jervis CMR, 2650 m, IN2017_V03_056, (-35.333, 151.258), 1 wet (AMS C.571611).

\section{Distribution}

Known only from the type locality.

Etymology: In reference to the colouration of its shell, derived from 'cuprosus' (Latin = coppery), adjective of feminine gender.

ZooBank registration: urn:Isid:zoobank.org:act:169E6E79-B8C7-4169-A321-2EF87AE84C71

Description. Shell (Fig. 4D) ( $S L=12.6, \mathrm{SW}=9$ ) sub-globose, thin-walled, semi-translucent.

Protoconch (Fig. 5A) multispiral, broadly conical, orange, of about 3 evenly convex whorls;

protoconch sculpture diagonally cancellate. Protoconch-teleoconch transition clearly

defined, weakly sinuate. Teleoconch of about 2.7 copper-hued whorls, suture moderately

impressed. Teleoconch whorls broad, strongly convex in outline, with no clearly defined

subsutural ramp. Teleoconch sculpture of dense, low, regularly spaced cords alternate

strong and weak (about 40 each on last whorl), latter becoming indistinct towards base of

last adult whorl. Microsculpture of very dense, barely detectable collabral growth lines.

Siphonal canal clearly demarcated from shell base, straight, sculptured with low longitudinal

cords. Aperture wide, ovate, more than two thirds of shell length; outer lip very thin. Anal

sinus indistinct.

Anatomy unknown. 
1170 Remarks

1171 See below for comparison with G. pomum n. gen. n. sp.

1172 Trochodaphne cuprosa n. gen. n. sp., in terms of its shell morphology, bears some similarity

1173 to the genus Lusitanops in its overall convex whorl outline, sculpture dominated by spiral

1174 elements, and shallow anal sinus, particularly when compared to Lusitanops dictyota

1175 Sysoev, 1997. The latter, however, has notably broader whorls than the type species. We

1176 are, however, reluctant to consider this new taxon as Lusitanops, as neither the type species

1177 L. Iusitanicus nor L. dictyota possess such a distinctly globose shell as that of $T$. cuprosa n.

1178 gen. n. sp., which in that regard more resembles G. pomum n. gen. n. sp. described herein

1179 than Lusitanops. Sysoev (1997) noted that L. dictyota does not possess a radula, however,

1180 no anatomical data is available for T. cuprosa. Furthermore, with the exception of L. dictyota

1181 (whose placement in the genus is based solely on shell characters), species of Lusitanops

1182 bear a weak and short siphonal canal (Bouchet \& Warén, 1980), whereas in T. cuprosa $\mathrm{n}$.

1183 gen. n. sp. the canal is of moderate length, and very clearly demarcated from the last adult

1184 whorl as seen on its left side (when observed in apertural view, see Fig. 4D). T. cuprosa n.

1185 gen. n. sp. is also similar to some species of Teretiopsis (e.g. T. abyssalis Kantor \& Sysoev,

1186 1989), however, the latter has a narrower shell with clearly angulated whorls. Some species

1187 in the genus Phymorhynchus (for example, P. major Bouchet \& Warén, 2001 or P. ovatus

1188 Bouchet \& Warén, 2001) also possess (sub)globose shells, with strongly convex whorls and

1189 closely set rounded cords, but both of these species are notably larger, with thick, chalky

1190 white shells. T. cuprosa n. gen. n. sp. may also superficially resemble Xanthodaphne Powell,

11911942 in that the latter also exhibits somewhat inflated whorls with distinct spiral elements;

1192 however, the type species $X$. membranacea has a well-developed anal sinus, a more 
1193 distinctly shouldered, less convex whorl profile, less prominent spiral sculpture, and is also 1194 far less globose than Trochodaphne n. gen.

1195 
1196 Discussion

1197 Genus-level systematics

1198 In order to apply genus names to the study material, the integrative approach described

1199 above was followed. The evidence forming the basis for our genus-level attributions is 1200 provided below.

1201 The examination of shell features was deemed sufficient to enable genus placement for four 1202 clades, namely Teretiopsis Kantor \& Sysoev, 1989, Mioawateria, Famelica and 1203 Rimosodaphnella. Although the radula is absent in Teretiopsis (Kantor \& Sysoev, 1989) and 1204 has not been studied in the latter three genera, each of these genera is characterised by a 1205 distinctive combination of shell features not reported for any other raphitomid genus 1206 (Bouchet \& Warén, 1980; Sysoev \& Kantor, 1987 for Famelica; Morassi \& Bonfitto, 2010 for 1207 Mioawateria; Bonfitto \& Morassi, 2013 for Rimosodaphnella).

1208 The attribution to Phymorhynchus of one clade (retrieved in the BI analysis only) was also 1209 supported by shell features. Although there is no published account on the radula of the type species, P. castaneus (Dall, 1895), species of Phymorhynchus possess large shells with 1211 strongly convex whorls bearing prominent spiral sculpture and with a very wide aperture 1212 lacking a subsutural sinus (Warén \& Bouchet, 2009). This unique combination of features 1213 was shared by all studied Australian samples in the clade.

1214 However, most clades retrieved by our analysis could only be preliminarily associated with 1215 genera that are not well-defined conchologically. In such cases, an assessment of combined 1216 morpho-anatomical features formed the basis for our genus attribution.

1217 Species of three clades (forming the 'Bathybela-like' group in Fig. 7) exhibited large shells 1218 with a shallow anal sinus and comparatively weak sculpture. This combination of characters 1219 is found in at least three genera, namely Bathybela, Spergo and Pontiothauma. Given this 
1220

1221

1222

1223

1224

1225

1226

1227

1228

1229

1230

1231

1232

1233

1234

1235

1236

1237

1238

1239

1240 60

1243

non-exclusive character combination, the need of taxonomic revision has been invoked for all three (Bouchet \& Warén, 1980; Sysoev \& Bouchet, 2001). Radular details have been published for type material of the type species of Spergo (Dall, 1895, pl. 24, fig $1 \mathrm{~h}$ ) and Ponthiotauma (Page, 1903, pl. 42, figs 5-9, 14), while the radula of the type species of Bathybela, B. nudator (Locard, 1897), is figured by Bouchet \& Warén (1980 p. 10, fig. 16). Nodothauma magnifica n. gen. n. sp. lacks venom apparatus and radula, and could therefore not convincingly be assigned to any of the above genera. While neither of the remaining two clades showed a radula referable to Bathybela, these did exhibit radulae typical of Spergo and Pontiothauma respectively, leading to the attribution to these two genera.

Samples of five clades (corresponding to Gymnobela s.l. of Fig. 7) exhibited shells that, according to the current taxonomic treatment (see Sysoev \& Ivanov, 1985; Sysoev, 1990; Sysoev, 1996b; Sysoev \& Bouchet, 2001), were attributable to the genus Gymnobela. The description of the type species G. engonia Verril, 1884 contains no account of the radula, but the hypodermic tooth is illustrated in Bouchet \& Warén (1980, p. 12, fig. 31). All clades in the Gymnobela s.l. group varied considerably in the radula of their constituent samples, with only one containing specimens with radular features resembling those of G. engonia. Consequently, this latter clade is attributed to Gymnobela s.s., and new generic names, Fusobela, Gladiobela, Pagodibela and Austrobela are here introduced for the taxa represented by the remaining four clades.

Similarly, samples of two clades (corresponding to Pleurotomella s.l., Fig. 7) had shell features corresponding to those of Pleurotomella (see Bouchet \& Warén, 1980). The radula of the type species $P$. packardii is known only from an illustration in Bouchet \& Warén (1980, p. 11, fig. 26). Species of the two clades possessed different radulae, but only one 
1244 clade exhibited a radular morphology similar to that of $P$. packardii. From this clade, we 1245 examined the radula of Pleurotomella sp. 1 and for a further specimen (AMS C.487456), 1246 conspecific with Pleurotomella sp. 2 (WAM S32236) (Fig S2). Both radulae appear very 1247 similar to that figured in Bouchet \& Warén (1980) for $P$. packardii, hence this clade is 1248 attributed to Pleurotomella. A new genus name, Glaciotomella n. gen., is proposed for 1249 species of the other clade, exhibiting a Pleurotomella-like shell albeit with a rather divergent 1250 radula from that of $P$. packardii. In our molecular analysis (Fig. 2), species of Pleurotomella 1251 show a degree of divergence comparable to that of the nodes separating different genera in 1252 the same analysis. This indication of comparatively distant relationships suggests the need 1253 for further taxonomic investigation, which cannot be conducted based on our limited data. 1254 One clade contained a specimen (AMS C.482290) exhibiting a nearly identical shell to the 1255 holotype of Theta lyronuclea (type species of Theta), both in its teleoconch and protoconch 1256 morphology. Furthermore, its radula was very similar to that figured for that species by 1257 Bouchet \& Warén (1980, p. 9, fig. 13). In spite of the considerable geographic distance of its 1258 collecting site (off E Australia) from the type locality of T. lyronuclea (off Bermuda), AMS 1259 C.482290 was considered as belonging to this species. Consequently, the clade in which it 1260 forms a part was assigned to Theta. Known examples of conoidean species with global, 1261 transoceanic distributions are rare. However, the phenomenon has been reported for the 1262 turrid Cryptogemma benthima (Dall, 1908) (Zaharias et al., 2020).

1263 One clade contained two species sharing a fusiform shell with cylindrical whorl periphery, as 1264 well as very thick, double-barbed hypodermic teeth with a large, coarse base. As this 1265 character combinaton is unique within the Raphitomidae, the clade was assigned to a new 1266 genus, Austrotheta n. gen. 
1267 One sample (AMS C.519335) not clustering with any other sample could be readily assigned

1268 to Typhlosyrinx due to its large, very elongate shell with an ovate last adult whorl and a very

1269 short siphonal canal, and in its large, double-barbed hypodermic teeth (Bouchet \& Sysoev,

1270 2001)

1271 Two unrelated species (AMS C.482283 and AMS C.571611) shared a nearly globose shell,

1272 with a high whorl expansion rate (sensu Raup, 1961) and sculpture of densely set, weak

1273 cordlets. Not observed in any known genus of the Raphitomidae, these combined characters

1274 here prompted the establishment of two new genera; Globodaphne n. gen. and

1275 Trochodaphne n. gen.

1276 Two additional unrelated samples, that did not cluster with any of the other clades within

1277 this analysis (AMS C.519362 and AMS C.571734), shared a relatively large, subglobose, thin-

1278 walled shell with weakly developed sculpture. These combined features are referable to

1279 Xanthodaphne. These two unrelated taxa, however, exhibit rather different hypodermic

1280 teeth (not shown). The type species of Xanthodaphne, X. membranacea (Watson, 1886),

1281 was described for the deep sea of New Zealand based on an empty shell, and for which no

1282 radular data is available. Bouchet \& Warén (1980; p. 8, fig. 9) figured the radula (but not the

1283 shell) of a specimen from "the bathyal of New Zealand", albeit with no repository detail

1284 provided. The radula figured therein exhibits a single-bladed tooth, which differs from the

1285 tooth of both AMS C.519362 (with two weak barbs, one serrated) and AMS C.571734 (with

1286 two distinct barbs). Pending thorough taxonomic definition of Xanthodaphne, we therefore

1287 refrain from attributing these two clades to this or any other genus.

1288 An additional specimen that did not cluster within any of the other clades (AMS C.571643)

1289 exhibited a conical, unsculptured shell resembling that of Abyssothauma Sysoev, 1996 and 
1290 some species of Eubela Dall, 1889. Unfortunately, the radula preparation was unsuccessful 1291 and genus attribution was therefore not attempted.

1292 Deep-sea raphitomid species have been assigned to genera based on morphology only 1293 (Bouchet \& Warén, 1980; Sysoev \& Ivanov, 1985; Sysoev \& Kantor, 1987; Sysoev, 1996a; 1294 Sysoev, 1996b; Sysoev, 1997; Sysoev \& Bouchet, 2001; Figueeira \& Absalao, 2012). These 1295 attributions appear as largely driven by shell morphology, despite, in some cases, 1296 substantial differentiation in radular morphology can be observed in these taxonomic 1297 groups. The present work confirms that (arguably) homogenous shell characters in deep-sea 1298 raphitomids are of limited taxonomic utility as conchologically similar clusters vary considerably in their radular anatomy. Within the Conoidea, there are numerous examples 1300 of taxa with very similar shells differing significantly in their radular morphology (Kantor et 1301 al., 2008), such as for the two deep-sea raphitomid genera Typhlosyrinx and Leiosyrinx Bouchet \& Sysoev, 2001 (Bouchet \& Sysoev, 2001). The suitability of the radula as a diagnostic character compared to that of the shell was molecularly tested for some turriform conoideans (Kantor et al., 2018). There, the variation in radular morphology and considerable genetic differentiation between highly convergent shell morphotypes was regarded as an indication of shell-wise cryptic genus-level diversity. Our study demonstrates 1307 that, to some extent, this applies also to several deep-sea genera of the Raphitomidae. Conversely, two species of the shallow-water raphitomid genus Hemilienardia possess a 1309 remarkably divergent radula from that of their congeners and other raphitomids (Fedosov et al., 2017). We therefore emphasise the importance of an integrative approach, combining 1311 morphological and molecular data, when studying the taxonomy of turriform conoideans. 1312 Our results also suggest that maintaining the integrity of some of the traditionally highly speciose genus concepts (such as Gymnobela s.I. or Pleurotomella s.I.) is untenable unless a 
1314

1315 all deep-sea taxa studied here.

Patterns in morphological characters

Shell 2018; Hallan et al., 2019).

number of well-established and morphologically highly distinct genera are synonymised.

Such a decision is in accordance with studies on other conoidean groups (Puillandre et al., 2015; Fedosov et al., 2020). Therefore, twelve new genera are introduced herein in order to avoid synonymising well-established genus names.

Three broad shell morphological 'types' can be recognised: (a) large fusiform, with relatively weak sculpture, (b) a fusiform-biconical, and (c), with comparatively prominent sculpture, convex whorls with deeply impressed suture, and a sharply delineated siphonal canal. These types are rather conserved morphologies distributed in non-related lineages across the phylogenetic tree (Fig. 7). Other, less prevalent types (e.g. the globose Trochodaphne n. gen./Globodaphne n. gen. and biconical Biconitoma n. gen./Aplotoma n. gen.) also occur in unrelated lineages (Fig. 7). Such a non-monophyletic distribution of similar shell morphologies is not unexpected; shell convergence within the Conoidea is widely acknowledged, and reported for several families (e.g. Bouchet et al., 2011; Kantor et al.,

Several shallow-water raphitomids, such as Hemilienardia and Kermia Oliver, 1915 (Fedosov \& Puillandre, 2012) possess thick, elaborate sculpture, commonly with reinforcement of the aperture. Very few such shell-strengthening strategies have been encountered in the deepsea taxa studied herein (Figs 3,6). While sculptural elements are generally seen, reinforcement by means of thickening or sculptural elaboration of the aperture is absent in 
1338 Radula

1339 Three configurations of the hypodermic tooth were encountered: double-barbed, awl1340 shaped with dorsal blade, and awl-shaped with no distinct blade. These are distributed 1341 across the tree irrespective of supra-specific phylogenetic relationships. For instance, the 1342 unrelated Austrobela, Pontiothauma and Typhlosyrinx all have double-barbed teeth (Fig. 7). 1343 However, genus-level synapomorphies can be identified in most genera by considering a 1344 combination of characters, such as morphology and size of barbs and blades, the relative 1345 length of the adapical opening, and base morphology and texture. Whether such conserved 1346 morphology reflects true phylogenetic signal and/or identical prey type, or both, remains to 1347 be established. While polychaete fragments have been encountered in some taxa (see 1348 Systematics), the identification of such fragments is inadequate in order to infer dietary 1349 patterns among these taxa.

1350 A number of examined species have lost the venom apparatus (Fig. 7), the loss of which is 1351 known to occur in distantly related clades in the Raphitomidae and in Conoidea more 1352 broadly (Kantor \& Sysoev, 1986; Kantor \& Sysoev, 1989; Taylor, 1990; Kantor \& Taylor, 2002; 1353 Medinskaya \& Sysoev, 2003; Castelin et al., 2012). Kantor and Sysoev (1989) argued that in 1354 conoideans where rhynchostomal lips and the rhynchodeal introvert develop and become 1355 more significant for prey capture, the necessity of the radula decreases, potentially resulting 1356 in the subsequent loss of the radula and venom apparatus. Members of another conoidean 1357 family, Terebridae, where radula, venom gland and proboscis have been repeatedly lost also 1358 typically possess a rhynchodeal introvert (Castelin et al., 2012; Fedosov et al., 2020). Ball et 1359 al. (1997) suggested that the reduction or absence of the proboscis in raphitomids were 1360 indicative of paedomorphic states (see Ponder \& Lindberg, 1997 for discussion on potential 1361 heterochrony in gastropods) and Kantor \& Taylor (2002) proposed that the loss of radula 
1362

1363

1364

1365

1366

1367

1368

1369

1370

1371

1372

1373

1374

1375

1376

1377

1378

1379

1380

1381

1382

1383

1384

Bouchet \& Warén (1994).

\section{Eyes}

and venom apparatus may also be linked to paedomorphosis. Ball (pers. comm. as provided in Kantor \& Taylor, 2002) reported that the venom gland is among the last of the major foregut organs to develop during ontogeny. Many of the new taxa herein possess thick rhynchostomes and well-developed introverts, such as Glaciotomella investigator n. gen. n. sp., Nodothauma magnifica n. gen. n. sp., B. cretosa n. gen. n. sp., G. pomum n. gen. n. sp. and P. cirricsulcata n. gen. n. sp. Nevertheless, there is no clear correlation between the presence of a rhynchodeal introvert and the reduction or loss of radula and venom apparatus - the venom apparatus and radula are lost in G. pomum n. gen. n. sp. and $N$. magnifica n. gen. n. sp., but are well-developed in P. cirrisulcata n. gen. n. sp. and B. cretosa, n. gen. n. sp. and all four taxa possess a a well-developed introvert.

Bouchet \& Warén (1980) noted an unexpectedly high proportion of abyssal turriform conoidean species that possess eyes in their study of the North Atlantic fauna, which is consistent with our results. Some taxa, such as Austrobela and Spergo have comparatively large and well-developed eyes in all species studied here, suggesting that this feature may be diagnostic for these genera. In the majority of lineages, such as Gymnobela,

Pontiothauma, Gladiobela n. gen., Pueridaphne n. gen., Rimosodaphnella and Glaciotomella n. gen., the eyes are very small to minuscule. For only one taxon, Biconitoma n. gen., no eyes were observed. Juvenile specimens of $N$. magnifica n. gen. n. sp. possess large eyes whereas in adults the eyes are in part covered by epidermis. Juveniles with eyes and blind conspecific adults have been reported for deep-sea species of turriform conoideans by 
Bathymetric distribution

1387 Our data (Fig. 8) show that, in the deep waters of SE Australia, genera of Raphitomidae

Antarctic region (Kantor et al., 2016).

logistics. Often, due to great distances and technical difficulties, only a relatively limited number of samples can be obtained in a single voyage. Even when characterisation of the benthic fauna is the primary aim, adapting the sampling methodology to target a specific 1405 taxonomic group is often impractical. Such limitations have affected deep-sea surveys also in SE Australia, that are the main source of material for this study. In the gastropod material 1407 collected, in particular, there was a bias towards large forms. As small snails are a significant 1408 portion of the overall turriform conoidean diversity (Bouchet et al., 2009), it is possible that 1409 
1410 fauna. As a consequence, the taxonomical and geographical coverage discussed below

1411 cannot be exhaustive.

1412 Prior to this study, the distribution of deep-sea raphitomid genera in Australia was primarily 1413 known from museum specimen data. Only scattered records for eight genera were 1414 available: Gymnobela (Torres Strait to S Tas), Nepotilla Hedley, 1918 (Central Qld to SW 1415 WA), Pleurotomella (Torres Strait to GAB), Taranis (NT to Eyre Peninsula), Thatcheria Angas, 14161877 (N WA), Veprecula (Central WA to N Tas), Xanthodaphne (S NSW) and Spergo (WA) 1417 (source ALA, http://www.ala.org.au). However, many of these records occur outside our 1418 target area (southern and eastern coast) and/or are based on material not examined in this 1419 study. Furthermore, this material was identified based on shell morphology and is therefore 1420 possibly of unreliable identification, given issues with shell homoplasy raised previously. For these reasons, these records are here ignored, with the discussion of diversity and 1422 distribution of SE Australian deep-sea raphitomids below based exclusively on our study 1423 material.

1424 One of the most apparent outcomes of this study is the high level of previously 1425 unrecognised diversity in the deep-sea raphitomid fauna of SE Australia. More than half of 1426 the genera and most of the species (87\%) present in the area are undescribed, which is 1427 consistent with reported estimates of unnamed turriform conoideans of the tropical Indo1428 Pacific (Bouchet et al., 2008).

1429 Our data further indicate that the raphitomid fauna of the study area includes 58 species 1430 from at least 24 genera. These figures, amounting to over one-third of the overall accepted 1431 raphitomid genera and more than $7 \%$ of the named species, indicate that the diversity of 1432 Raphitomidae in temperate SE Australia is significantly greater than previously understood. 
1434 Biogeographic overlap with adjacent basins

1435 Assessing the extent and composition of raphitomid diversity in the study area compared 1436 with those of other deep-sea regions is challenging, due to geographical and methodological 1437 biases. Firstly, the faunistic coverage on Raphitomidae in the deep sea is incomplete, with 1438 comparable data available only for some regions of the tropical SW Pacific (Bouchet et al., 1439 2009), Atlantic (Bouchet \& Warén, 1980; Figueeira \& Absalao, 2012) and Antarctica (Kantor 1440 et al., 2016). Secondly, these reports refer to areas of varying geographic extent and with 1441 different bathymetrical ranges (e.g. Barnard, 1963; Sysoev \& Ivanov, 1985; Sysoev, 1988; 1442 Sysoev, 1990; Sysoev, 1996b) and are thus of problematic comparison. Lastly, in most 1443 available studies, taxonomic treatments rest exclusively on morphological evidence and 1444 with no supporting molecular data. The comparisons below are therefore: (a) limited to the 1445 deep sea of relatively well-studied neighbouring basins, (b) restricted to genus-level and (c) 1446 exploratory in nature, pending further collecting as well as taxonomic investigations.

1447 Our findings show minimal overlap with the raphitomid fauna of one directly adjacent basin, 1448 the Southern Ocean. Only one genus (Pleurotomella) and none of the 17 raphitomid species 1449 occurring in Antarctica (reviewed in Kantor et al., 2016) have been recorded in SE Australia. 1450 Interpretation of published data on shells and radulae of deep-sea raphitomids from the 1451 Cape Point region in South Africa (Barnard, 1963; Sysoev, 1996b), suggests that these areas 1452 share four genera with SE Australia (Famelica n. gen., Gymnobela, Pontiothauma and 1453 Theta). A similar comparison is more difficult with the fauna of the Nasca and Sala-y-Gomez 1454 ridges (SE Pacific; Sysoev \& Ivanov, 1985; Sysoev, 1990) for which only shell data is available. 1455 However, the evidence suggests that this area shares Pleurotomella and possibly Gymnobela 1456 and Austrobela n. gen. with SE Australia, although these conclusions remain untested, 1457 pending the availability of material suitable for molecular study from the relevant areas. 
1458

1459

1460

1461

1462

1463 1464 the study area.

1465

\section{Range size and endemism}

1467 The number (seven) and proportion (one third) of putative endemic genera found in this 1468 study are greater than those recorded for other realms. Five genera are endemic to the 1469

Nevertheless, where preliminary molecular data do exist (this, and other studies in preparation), they suggest, in combination with morphology, that some of the newly recognised genera (Austrobela n. gen., Pagodibela and Gladiobela n. gen.), as well as some other genera (e.g. Famelica, Spergo and Theta), have ranges extending well into the tropical Indo-Pacific. No evidence is available to date for Glaciotomella n. gen., Austrotheta n. gen. or any of the monotypic genera described herein to suggest that these may occur outside

south Australian realm and two are unique to the Coral Sea realm (sensu Costello et al., 2017). To date, only seven deep-sea raphitomid genera are known to be endemic to one single marine realm, namely Buccinaria Kittl, 1887, Rocroithys Sysoev \& Bouchet, 2001, Leiosyrinx (Bouchet \& Sysoev, 2001) for the Indo-Pacific realm; Abyssobela (Sysoev \& Kantor, 1986) and Vitjazinella for the Offshore W Pacific; Tuskaroia (Sysoev, 1988) for the N Pacific and Abyssothauma Sysoev, 1996 for South Africa. No endemic genera are found in the SE Pacific ridges mentioned above (Sysoev \& Ivanov, 1985; Sysoev, 1990) or in Antarctica (Kantor et al., 2016).

1477 The extension of the distribution range of deep-sea turriform conoideans is thought to 1478 depend on two alternative larval developmental strategies. Taxa with planktotrophic larvae 1479 are usually considered more effective dispersers than direct developers (with lecitotrophic 1480 larvae) and have greater ranges (Bouchet \& Warén, 1994). Planktotrophy can be assessed 1481 by the presence of a multispiral protoconch, while lecitotrophy is associated with a 
1482 paucispiral protoconch (Thorson, 1950). Species, for which examination of the protoconch

1483 was possible in this study, exhibited a multispiral protoconch, except those attributed to 1484 Pontiothauma. This is in accordance with the notion that planktotrophy is the dominant 1485 mode of development in deep-sea turriform conoideans (Bouchet \& Warén, 1994). While 1486 higher dispersal potential could in theory explain the wide ranges observed here for some 1487 genera, it does not provide sufficient justification for the potentially much more restricted 1488 ranges reported for other genera. It has been speculated that the larvae of many deep-sea 1489 turriform conoideans may undergo (total or partial) demersal development (Shimek, 1986; 1490 Bouchet \& Warén, 1994), known to purportedly reduce dispersal ability of some deep-sea 1491 invertebrates (Young et al., 2017). There is no evidence of demersal larval life in any of the 1492 genera studied here, and further ecological investigation is required to assess whether such 1493 a strategy can be linked to more restricted distribution ranges. The purported wide range of 1494 Ponthiothauma despite its lecitotrophic larva is also in disagreement with the general rule. 1495 However, it has been suggested that lecitotrophic larvae of some deep-sea gastropods are 1496 capable of spending longer periods as demersal, drifting, nonfeeding larvae and thus have a 1497 greater dispersal ability than commonly thought (Bouchet \& Warén, 1994).Environmental 1498 factors may also influence distribution patterns of raphitomid genera. Species of Buccinaria 1499 Kittl, 1887 are endemic to the Indo/Indo-Pacific realm, where they occur on reducing 1500 sediment at bathyal depths. It has been hypothesised that the absence of this genus from 1501 the neighbouring deep waters off NW Australia and the Arabian Sea may be due to the lack 1502 of such preferential substrate (Bouchet \& Sysoev, 1997).

1503 Our preliminary observations suggest that distribution patterns of deep-sea raphitomid 1504 genera can be highly heterogenous. While some genera seem to possess very wide ranges, 1505 others appear strictly endemic. However, further molecular and ecological data on 
1506 Raphitomidae worldwide are required to assess the real taxonomic diversity, and observed

1507 distribution patterns presented herein, as well as to further elucidate their underlying 1508 mechanisms. 
1509 Acknowledgments

1510 This work has been made possible through financial support from the Australian

1511 Government (ABRS grant RF217-57, principal investigator FC). The participation of AF was

1512 also supported by the Russian Science Foundation (grant 16-14-10118 to Yuri Kantor).

1513 Voyages in the GAB were part of: (a) the GAB Research Program [GABRP - a collaboration

1514 between BP, CSIRO, the South Australian Research and Development Institute (SARDI), the

1515 University of Adelaide, and Flinders University] and (b) the GAB Deepwater Marine Program

1516 (GABDMP - a CSIRO led research program sponsored by Chevron Australia]. Funding for the

1517 'Eastern Abyss' voyage (IN2017_V03) was provided by the Marine Biodiversity Hub (MBH),

1518 supported through the Australian Government's National Environmental Science Program

1519 (NESP). The 'Tasmanian seamounts' voyage (IN2018_V06) was sponsored by the CSIRO

1520 Marine National Facility (MNF), the NESP MBH and Parks Australia. The authors wish to

1521 thank the CSIRO MNF for its support in the form of sea time onboard, support personnel,

1522 scientific equipment and data management. We also thank the scientific staff and crew who

1523 participated in all voyages generating the samples studied herein.

1524 The MNHN samples used in this study originates from shore-based expeditions (PANGLAO

1525 2004, PAPUA NIUGINI) and deep-sea cruises (AURORA 2007, BOA1, EBISCO, SALOMON 2)

1526 conducted by MNHN, Pro-Natura International (PNI) and Institut de Recherche pour le

1527 Développement as part of the Our Planet Reviewed and the Tropical Deep-Sea Benthos

1528 programs. Scientific partners included the University of Papua New Guinea (UPNG), the

1529 University of San Carlos, Cebu City, and the Philippines Bureau of Fisheries and Aquatic

1530 Research; funders and sponsors included the Total Foundation, Prince Albert II of Monaco

1531 Foundation, Stavros Niarchos Foundation, and Richard Lounsbery Foundation. All

1532 expeditions operated under the regulations then in force in the countries in question and 
1533

1534 We would also like to thank the scientific team of the BICOSE cruise (P.I. M. Cambon-

1535 Bonavita, Ifremer), especially the team of the ROV 'Victor 6000'.

1536

1537

1538

1539

1540

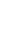

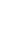

1543 We are indebted to several people providing photos of types and other relevant specimens:

1544 Andreia Salvador (NHMUK, London), Ellen Strong (NMNH, Washington), Alexander Sysoev

1545 (ZMMU, Moscow), Giorgio Teruzzi and Anna Alessandrello (MSNM, Milan), Kazunori

1546 Hasegawa (NSMT, Tokyo) and Bram van der Bijl (NMNL, Leiden).

1547 We also thank Yuri Kantor for assistance with the interpretation of radular characters and

1548 Winston Ponder (AMS) for useful discussions about general neogastropod anatomy. Finally,

1549 two anonymous reviewers are thanked for their helpful suggestions which served to

1550 improve the manuscript. 
1551 References

1552

1553

1554

1555

1556

1557

1558

1559

1560

1561

1562

1563

1564

1565

1566

1567

1568

1569

1570

1571

1572

1573

1574

1575

1576

1577

1578

1579

1580

Abdelkrim J, Aznar-Cormano L, Fedosov AE, Kantor YI, Lozouet P, Phuong MA, Zaharias P, Puillandre N. 2018a. Exon-Capture-Based Phylogeny and Diversification of the Venomous Gastropods (Neogastropoda, Conoidea). Molecular Biology and Evolution 35: 2355-2374.

Abdelkrim J, Aznar-Cormano L, Buge B, Fedosov A, Kantor Y, Zaharias P, Puillandre N. 2018b. Delimiting species of marine gastropods (Turridae, Conoidea) using RADsequencing in an integrative taxonomy framework. Molecular Ecology 27(22):45914611.

Arntz W, Brey T. 2003. The Expedition ANTARKTIS XIX/5 (LAMPOS) of RV "Polarstern" in 2002. Bremerhaven: Alfred Wegener Institute for Polar and Marine Research.

Ball AD, Andrews EB, Taylor JD. 1997. The ontogeny of the pleurembolic proboscis in Nucella lapillus (Gastropoda: Muricidae). Journal of Molluscan Studies 63: 87-99.

Barnard KH. 1963. Deep sea Mollusca from West of Cape Point, South Africa. Annals of the South African Museum 46: 407-453.

Bonfitto A, Morassi M. 2013. New Indo-Pacific species of Rimosodaphnella Cossmann, 1916 (Gastropoda: Conoidea): a genus of probable Tethyan origin. Molluscan Research 33: 230-236.

Bouchet P, Bary S, Heros V, Marani G. 2016. How many species of molluscs are there in the world's oceans, and who is going to describe them? Memoires du Museum National d'Histoire Naturelle 208: 9-24.

Bouchet P, Heros V, Lozouet P, Maestrati P. 2008. A quarter - century of deep-sea malacological exploration in the South and West Pacific: where do we stand? How far to go?

Bouchet P, Kantor YI. 2004. New Caledonia: The major centre of biodiversity for volutomitrid molluscs (Mollusca: Neogastropoda: Volutomitridae). Systematics and Biodiversity 1: 467-502.

Bouchet P, Kantor YI, Sysoev A, Puillandre N. 2011. A new operational classification of the Conoidea (Gastropoda). Journal of Molluscan Studies 77: 273-308. 
1581

1582

1583

1584

1585

1586

1587

1588

1589

1590

1591

1592

1593

1594

1595

1596

1597

1598

1599

1600

1601

1602

1603

1604

1605

1606

1607

1608

1609

1610

1611

Bouchet P, Lozouet P, Sysoev A. 2009. An inordinate fondness for turrids. Deep-Sea Research Part II Topical Studies in Oceanography 56: 1724-1731.

Bouchet P, Sysoev A. 1997. Revision of the Recent species of Buccinaria (Gastropoda: Conoidea), a genus of deep-water turrids of Tethyan origin. Venus (Tokyo) 56: 93119.

Bouchet P, Sysoev A. 2001. Typhlosyrinx-like tropical deep-water turriform gastropods (Mollusca, Gastropoda, Conoidea). Journal of Natural History 35: 1693-1715.

Bouchet P, Warén A. 1980. Revision of the north east Atlantic bathyal and abyssal Turridae (Mollusca, Gastropoda). Journal of Molluscan Studies Supplement 8: 1-119.

Bouchet P, Warén A. 1994. Ontogenetic migration and dispersal of deep-sea gastropod larvae. Reproduction, larval biology, and recruitment of the deep-sea benthos.: Columbia University Press. 98-117.

Castelin M, Puillandre N, Kantor Y, Modica MV, Terryn Y, Cruaud C, Bouchet P, Holford M. 2012. Macroevolution of venom apparatus innovations in auger snails (Gastropoda; Conoidea; Terebridae). Molecular Phylogenetics and Evolution 64: 21-44.

Clarke AH. 1959. New abyssal mollusks from off Bermuda collected by the Lamont geological Observatory Research vessels. Proceedings of the Malacological Society of London 38: 231-238.

Costello MJ, Tsai P, Wong PS, Cheung AKL, Basher Z, Chaudhary C. 2017. Marine biogeographic realms and species endemicity. Nature Communications 8: 1057.

Dall WH. 1895. Report on the Mollusca and Brachiopoda dredged in deep water, chiefly near the Hawaiian Islands, with illustrations of hitherto unfigured species from Northwest America. Proceedings of the United States National Museum. 17: 675733.

Dall WH. 1908. The Mollusca and the Brachiopoda. (Reports on. the dredging operations off the west coast of Central America to the Galapagos, to the west coast of Mexico, and in the Gulf of California, in charge of Alexander Agassiz, carried on by the U. S. fish commission steamer "Albatross," during 1891, Lieut. Commander Z. L. Tanner, U. S. N., commanding. 37. Reports on the scientific results of the expedition to the eastern tropical Pacific, in charge of Alexander Agassiz, by the U, S. fish commission steamer "Albatross," from October. 1904, to March, 1906, Lieut Commander L. M. Garrett, U. 
1612

1613

1614

1615

1616

1617

1618

1619

1620

1621

1622

1623

1624

1625

1626

1627

1628

1629

1630

1631

1632

1633

1634

1635

1636

1637

1638

1639

1640

1641

1642

1643

S. N., commanding. 14). Cambridge. Mass Bull Mus Comp Zool Harvard Coll 43: (203$487+222$ I).

Dayrat B, Tillier A, Lecointre G, Tillier S. 2001. New clades of euthyneuran gastropods (Mollusca) from 28S rRNA sequences. Molecular Phylogenetics and Evolution 19: 225-235.

Fedosov AE, Malcolm G, Terryn Y, Gorson J, Modica MV, Holford M, Puillandre N. 2020. Phylogenetic classification of the family Terebridae (Neogastropoda: Conoidea). Journal of Molluscan Studies.

Fedosov AE, Puillandre N. 2012. Phylogeny and taxonomy of the Kermia-Pseudodaphnella (Mollusca: Gastropoda: Raphitomidae) genus complex: a remarkable radiation via diversification of larval development. Systematics and Biodiversity 10: 447-477.

Fedosov AE, Stahlschmidt P, Puillandre N, Aznar-Cormano L, Bouchet P. 2017. Not all spotted cats are leopards: evidence for a Hemilienardia ocellata species complex (Gastropoda: Conoidea: Raphitomidae). European Journal of Taxonomy 268: 1-20.

Figueeira RMA, Absalao RS. 2012. Deep-water Raphitomidae (Mollusca, Gastropoda, Conoidea) from the Campos Basin, southeast Brazil. Zootaxa 3527: 1-27.

Folmer O, Black M, Hoeh W, Lutz R, Vrijenhoek R. 1994. DNA primers for amplification of mitochondrial cytochrome c oxidase subunit I from diverse metazoan invertebrates. Molecular Marine Biology and Biotechnology 3: 294-299.

Galindo LA, Puillandre N, Strong EE, Bouchet P. 2014. Using microwaves to prepare gastropods for DNA barcoding. Mol Ecol Resour 14: 700-705.

Hallan A, Criscione F, Fedosov AE, Puillandre N. 2019. Bouchetispira ponderi n. sp. (Conoidea: Bouchetispiridae), a new deep-sea gastropod from temperate Australia. Molluscan Research: 1-7.

Horton T, Kroh A, Ahyong S, Bailly N, Boyko CB, Brandão SN, Costello MJ, Gofas S, Hernandez F, Holovachov O, Mees J, Paulay G, Rosenberg G, Decock W, Dekeyzer S, Lanssens T, Vandepitte L, Vanhoorne B, Verfaille K, Adlard R, Adriaens P, Agatha S, Ahn KJ, Akkari N, Alvarez B, Anderson G, Angel MV, Arango C, Artois T, Atkinson S, Bank R, Barber A, Barbosa JP, Bartsch I, Bellan-Santini D, Bernot J, Berta A, Bezerra TN, Bieler R, Blanco S, Blasco-Costa I, Blazewicz M, Bock P, Böttger-Schnack R, Bouchet P, Boury-Esnault N, Boxshall G, Bray R, Breure B, Bruce NL, Cairns S, Cárdenas P, Carstens E, Chan BK, Chan TY, Cheng L, Churchill M, Coleman CO, 
1644

1645

1646

1647

1648

1649

1650

1651

1652

1653

1654

1655

1656

1657

1658

1659

1660

1661

1662

1663

1664

1665

1666

1667

1668

1669

1670

1671

1672

1673
Collins AG, Corbari L, Cordeiro R, Cornils A, Coste M, Crandall KA, Cremonte F, Cribb T, Cutmore S, Dahdouh-Guebas F, Daly M, Daneliya M, Dauvin JC, Davie P, De Broyer C, De Grave S, de Mazancourt V, de Voogd NJ, Decker P, Decraemer W, Defaye D, d'Hondt JL, Dohrmann M, Dolan J, Domning D, Downey R, Drapun I, Ector L, Eisendle-Flöckner U, Eitel M, Encarnação SCd, Enghoff H, Epler J, EwersSaucedo C, Faber M, Feist S, Figueroa D, Finn J, Fišer C, Fordyce E, Foster W, Frank JH, et al. 2019. World Register of Marine Species (WoRMS): WoRMS Editorial Board.

Jovelin R, Justine J-L. 2001. Phylogenetic relationships within the polyopisthocotylean monogeneans (Platyhelminthes) inferred from partial 28S rDNA sequences. International Journal for Parasitology 31: 393-401.

Kantor YI, Fedosov AE, Puillandre N. 2018. New and unusual deep-water Conoidea revised with shell, radula and DNA characters. Ruthenica 28: 47-82.

Kantor YI, Harasewych MG, Puillandre N. 2016. A critical review of Antarctic Conoidea (Neogastropoda). Molluscan Research 36: 153-206.

Kantor YI, Puillandre N. 2012. Evolution of the radular apparatus in Conoidea (Gastropoda: Neogastropoda) as inferred from a molecular phylogeny. Malacologia 55: 55-90.

Kantor YI, Puillandre N, Olivera BM, Bouchet P. 2008. Morphological proxies for taxonomic decision in turrids (Mollusca, Neogastropoda): a test of the value of shell and radula characters using molecular data. Zoological Science (Tokyo) 25: 1156-1170.

Kantor YI, Strong EE, Puillandre N. 2012. A new lineage of Conoidea (Gastropoda: Neogastropoda) revealed by morphological and molecular data. Journal of Molluscan Studies 78: 246-255.

Kantor YI, Sysoev A. 1986. A new genus and new species from the family Turridae (Gastropoda, Toxoglossa) in the northern part of the Pacific Ocean. Zoologicheskii Zhurnal 65: 485-498.

Kantor YI, Sysoev A. 1989. The morphology of toxoglossan gastropods lacking a radula, with a description of new species and genus of Turridae. Journal of Molluscan Studies 55: 537-549.

Kantor YI, Taylor JD. 2002. Foregut anatomy and relationships of raphitomine gastropods (Gastropoda: Conoidea: Raphitominae). Bollettino Malacologico 38: 83-110. 
1674

1675

1676

1677

1678

1679

1680

1681

1682

1683

1684

1685

1686

1687

1688

1689

1690

1691

1692

1693

1694

1695

1696

1697

1698

1699

1700

1701

1702

1703

1704

Lalli CM, Parsons TR. 1997. CHAPTER 7 - BENTHOS. In: Lalli CM and Parsons TR, eds. Biological Oceanography: An Introduction (Second Edition). Oxford: ButterworthHeinemann. 177-195.

Linse K, Brandt A, Bohn JM, Danis B, De Broyer C, Ebbe B, Heterier V, Janussen D, Lopez Gonzalez PJ, Schueller M, Schwabe E, Thomson MRA. 2007. Macro- and megabenthic assemblages in the bathyal and abyssal Weddell Sea (Southern Ocean). Deep-Sea Research Part II Topical Studies in Oceanography 54: 1848-1863.

MacIntosh H, Althaus F, Williams A, Tanner JE, Alderslade P, Ahyong ST, Bax N, Criscione F, Crowther AL, Farrelly CA, Finn JK, Goudie L, Gowlett-Holmes K, Hosie AM, Kupriyanova E, Mah C, McCallum AW, Merrin KL, Miskelly A, Mitchell ML, Molodtsova T, Murray A, O’Hara TD, O'Loughlin PM, Paxton H, Reid AL, Sorokin SJ, Staples D, Walker-Smith G, Whitfield E, Wilson RS. 2018. Invertebrate diversity in the deep Great Australian Bight (200-5000 m). Marine Biodiversity Records 11: 23.

McEnnulty FR, Gowlett-Holmes KL, Williams A, Althaus F, Fromont J, Poore GCB, O'Hara TD, Marsh L, Kott P, Slack-Smith S, Alderslade P, Kitahara MV. 2011. The deepwater megabenthic invertebrates on the western continental margin of Australia (100-1100 $\mathrm{m}$ depths): composition, distribution and novelty. Records of the Western Australian Museum Supplement 80: 1-191.

Medinskaya A, Sysoev A. 2003. The anatomy of Zemacies excelsa, with a description of a new subfamily of Turridae (Gastropoda, Conoidea). Ruthenica 13: 81-87.

Morassi M, Bonfitto A. 2010. New raphitomine gastropods (Gastropoda: Conidae: Raphitominae) from the South-West Pacific. Zootaxa 2526: 54-68.

Okusu A, Schwabe E, Eernisse DJ, Giribet G. 2003. Towards a phylogeny of chitons (Mollusca, Polyplacophora) based on combined analysis of five molecular loci. Organisms Diversity \& Evolution 3: 281-302.

Page S. 1903. On the Anatomy of the Prosobranch genus Pontiothauma E. A. Smith. Journal of the Linnean Society Zoology xxviii: pp. 455-462.

Palumbi SR. 1996. Nucleic acids 2: the polymerase chain reaction. Sinauer Associates, Inc.

Ponder WF, Lindberg DR. 1997. Towards a phylogeny of gastropod molluscs: an analysis using morphological characters. Zoological Journal of the Linnean Society 119: 83265. 
1705

1706

1707

1708

1709

1710

1711

1712

1713

1714

1715

1716

1717

1718

1719

1720

1721

1722

1723

1724

1725

1726

1727

1728

1729

1730

1731

1732

1733

1734

1735

1736

Puillandre N, Baylac M, Boisselier MC, Cruaud C, Samadi S. 2009. An integrative approach to species delimitation in Benthomangelia (Mollusca: Conoidea). Biological Journal of the Linnean Society 96: 696-708.

Puillandre N, Duda TF, Meyer C, Olivera BM, Bouchet P. 2015. One, four or 100 genera? A new classification of the cone snails. The Journal of molluscan studies 81: 1-23.

Puillandre N, Lambert A, Brouillet S, Achaz G. 2012. ABGD, Automatic Barcode Gap Discovery for primary species delimitation. Molecular Ecology 21: 1864-1877.

Puillandre N, Sysoev A, Olivera BM, Couloux A, Bouchet P. 2010. Loss of planktotrophy and speciation: geographical fragmentation in the deep-water gastropod genus Bathytoma (Gastropoda, Conoidea) in the western Pacific. Systematics and Biodiversity 8: 371-394.

Rambaut A, Drummond AJ, Xie D, Baele G, Suchard MA. 2018. Posterior Summarization in Bayesian Phylogenetics Using Tracer 1.7. Systematic Biology 67: 901-904.

Raup DM. 1961. The geometry of coiling in gastropods. Proceedings of the National Academy of Sciences of the United States of America 47: 602-609.

Röckel D, Korn W, Kohn AJ. 1995. Manual of the living Conidae, volume 1: Indo-pacific region. Verlag Christa Hemmen.

Ronquist F, Huelsenbeck JP. 2001. MRBAYES: Bayesian inference of phylogenetic trees. Bioinformatics 17: 754-755.

Rozewicki J, Yamada KD, Katoh K. 2017. MAFFT online service: multiple sequence alignment, interactive sequence choice and visualization.

Schepman MM. 1913. The Prosobranchia of the Siboga Expedition. Part V. Toxoglossa. Uitkomsten op zool., botan., oceanogr. en geol. gebied verzameld in Ned. Oost-Indie 1899-1900 a-b H.M. Siboga onder commando van Lt. t-z le kl. G. F. Tydeman, uitgegeven door Max Weber. Resultats des explorations zool., botan., oceanogr. et geol. entreprises aux Indes Neerlandaises Orientales en 1899-1900 a bord du Siboga sous le commandement de G. F. Tydeman publies par Max Weber. Leiden (E J Brill) 1913 Livr 64: (365-452).

Shimek RL. 1986. The biology of the northeastern Pacific Turridae. 5. Demersal development, synchronous settlement and other aspects of the larval biology of Oenopota levidensis. International Journal of Invertebrate Reproduction and Development 10: 313-333. 
1737 Simon C, Franke A, Martin A. 1991. The polymerase chain reaction: DNA extraction and 1738 amplification. NATO ASI Series Series H Cell Biology 57: 329-355.

1739 Sigwart JD, Sutton MD, Bennett KD. 2017. How big is a genus? Towards a nomothetic $1740 \quad$ systematics. Zoological Journal of the Linnean Society 183: 237-252.

1741 Stamatakis A. 2006. RAxML-VI-HPC: maximum likelihood-based phylogenetic analyses with 1742 thousands of taxa and mixed models. Bioinformatics 22: 2688-2690.

1743 Sysoev A, Bouchet P. 2001. New and uncommon turriform gastropods (Gastropoda: 1744 Conoidea) from the South-West Pacific. Memoires du Museum National d'Histoire $1745 \quad$ Naturelle 185: 271-320.

1746 Sysoev A, Ivanov DL. 1985. New taxa of the family Turridae (Gastropoda, Toxoglossa) from 1747 the Naska Ridge (south east Pacific). Zoologicheskii Zhurnal 64: 194-205.

1748 Sysoev A, Kantor YI. 1986. New and rare abyssal species of the family Turridae (Gastropoda, 1749 1750 Toxoglossa) in the northern part of the Pacific Ocean. Zoologicheskii Zhurnal 65: 1457-1469.

Sysoev A, Kantor YI. 1987. Three new species of the deep-sea mollusc genus Famelica (Gastropoda, Toxoglossa, Turridae). Zoologicheskii Zhurnal 66: 1255-1258.

Sysoev A, Kantor YI. 1990. A new genus and species of 'Cochlespira-like' turrids (Gastropoda, Toxoglossa, Turridae). Apex (Brussels) 5: 1-6.

Sysoev A. 1988. Ultra-abyssal findings of the family Turridae (Gastropoda, Toxoglossa) in the Pacific Ocean. Zoologicheskii Zhurnal 67: 965-973.

Sysoev A. 1990. Gastropods of the family Turridae (Gastropoda: Toxoglossa) of the Nasca and Sala-y-Gomez underwater ridges. Trudy Instituta Okeanologii Akademii Nauk SSSR 124: 245-260.

Sysoev A. 1996a. Deep-sea conoidean gastropods collected by the John Murray Expedition, 1933-34. Bulletin of the Natural History Museum Zoology Series 62: 1-30.

1762 Sysoev A. 1996b. Taxonomic notes on South African deep-sea conoidean gastropods (Gastropoda: Conoidea) described by K.H. Barnard, 1963. Nautilus 110: 22-29.

Sysoev A. 1997. Mollusca Gastropoda: new deep-water turrid gastropods (Conoidea) from eastern Indonesia. Memoires du Museum National d'Histoire Naturelle 172: 325-355.

Taylor JD. 1990. The anatomy of the foregut and relationships in the Terebridae. Malacologia 32: 19-34. 
1768

1769

1770

1771

1772

1773

1774

1775

1776

1777

1778

1779

1780

1781

1782

1783

1784

1785

1786

1787

Thorson G. 1950. Reproductive and larval ecology of marine bottom invertebrates. Biological Reviews Cambridge 25: pp. 1-45.

Türkay M, Pätzold J. 2009. Southwestern Indian Ocean - Eastern Atlantic Ocean, Cruise No. 63, January 24 - March 30, 2005, Cape Town (South Africa) - Mindelo (Cabo Verde) METEOR-Berichte. Hamburg. 100.

Warén A, Bouchet P. 2009. New gastropods from deep-sea hydrocarbon seeps off West Africa. Deep-Sea Research Part II Topical Studies in Oceanography 56: 2326-2349.

Watson RB. 1886. Report on the Scaphopoda and Gastropoda collected by H.M.S. 'Challenger' during the Years 1873-76. Zoology Challenger Expedition xv: v + 756 pp.

Williams A. 2018. IN2018_V06. Status and recovery of deep-sea coral communities on seamounts in iconic Australian marine reserves. $R V$ Investigator Voyage Summary. Hobart. 42.

Young CM, Arellano SM, Hamel J-F, Mercier A. 2017. Ecology and Evolution of Larval Dispersal in the Deep Sea. Evolutionary Ecology of Marine Invertebrate Larvae. Oxford: Oxford University Press.

Zaharias P, Kantor YI, Fedosov AE, Criscione F, Hallan A, Kano Y, Bardin J, Puillandre N. 2020. Just the once will not hurt: DNA suggests species lumping over two oceans in deep-sea snails (Cryptogemma). Zoological Journal of the Linnean Society. 
Figure 1. Distribution of deep-sea Raphitomidae in southern and eastern Australia. Numbers in circles mark type localities of species described herein, namely (1) Aplotoma braevitentaculata n. gen. n. sp. (2), Austrobela rufa n. gen. n. sp. (3); Austrotheta crassidentata n. gen. n. sp.; (4) Biconitoma cretosa n. gen. n. sp. (5), Fusobela parvioculata n. gen. n. sp. (6), Glaciotomella investigator n. gen. n. sp. (7), Gladiobela angulata n. gen. n. sp. (8), Globodaphne pomum n. gen. n. sp. (9), Nodothauma magnifica n. gen. n. sp. (10), Pagodibela maia n. gen. n. sp. (11), Pueridaphne cirrisulcata n. gen. n. sp. (12), Trochodaphne cuprosa $n$. gen. $n$. sp. Shades correspond to areas targeted by sampling: A. the GAB, B. the east coast, C. Tasmanian seamounts (see text). Dashed lines mark limits among marine realms (numbered as in Costello et al., 2017). 
Figure 2. Bayesian consensus phylogram based on analyses of the concatenated COI, 16S, $12 \mathrm{~S}, 28 \mathrm{~S}$ and H3 sequences. Thick lines mark branches consistent with the topology of the ML tree. Numbers above branches indicate nodal support (\%) by Bayesian posterior probabilities (BPP). Numbers below branches indicate nodal support (\%) by ML bootstrap (BTSP). BPP and BTSP values of $100 \%$ are both represented by asterisks. Outgroup taxa are not shown. Names of species described herein are in bold. 


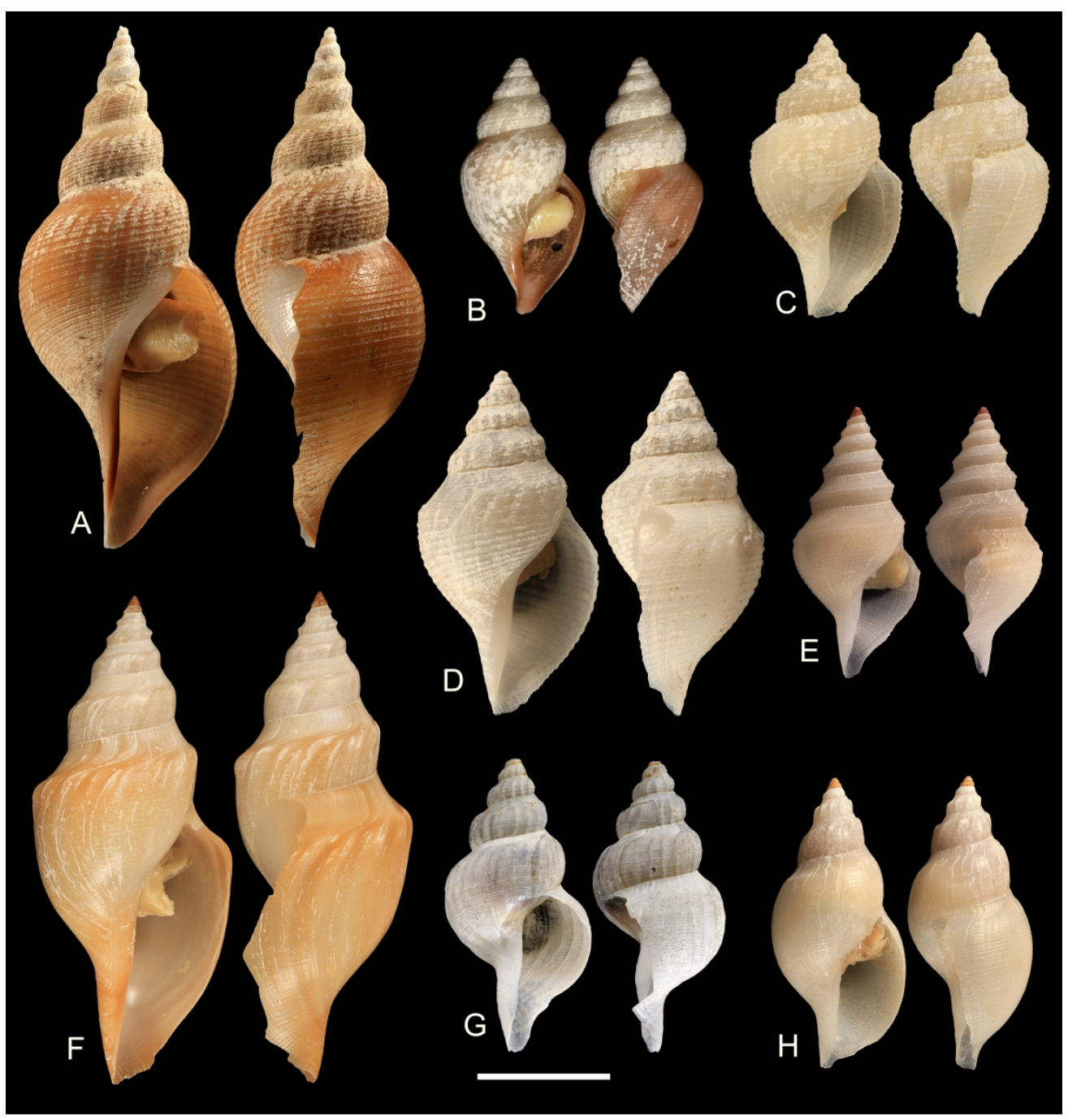

Figure 3. Shells of species described herein. A, Notothauma magnifica n. gen. n. sp., holotype AMS C.532707; B, Fusobela parvioculata n. gen. n. sp., holotype TMAG E59231; C, Aplotoma braevitentaculata n. gen. n. sp., holotype AMS C.571635; D, Biconitoma cretosa n. gen. n. sp., holotype AMS C.482313. E, Pagodibela maia n. gen. n. sp., holotype AMS C.571678; F, Austrobela rufa n. gen. n. sp., holotype AMS

C.571709; G, Glaciotomella investigator n. gen. n. sp., holotype AMS C.571621; H, Austrotheta crassidentata n. gen. n. sp., holotype AMS C.519302. Scale bar 20 mm (A), 10 mm (B-H). 


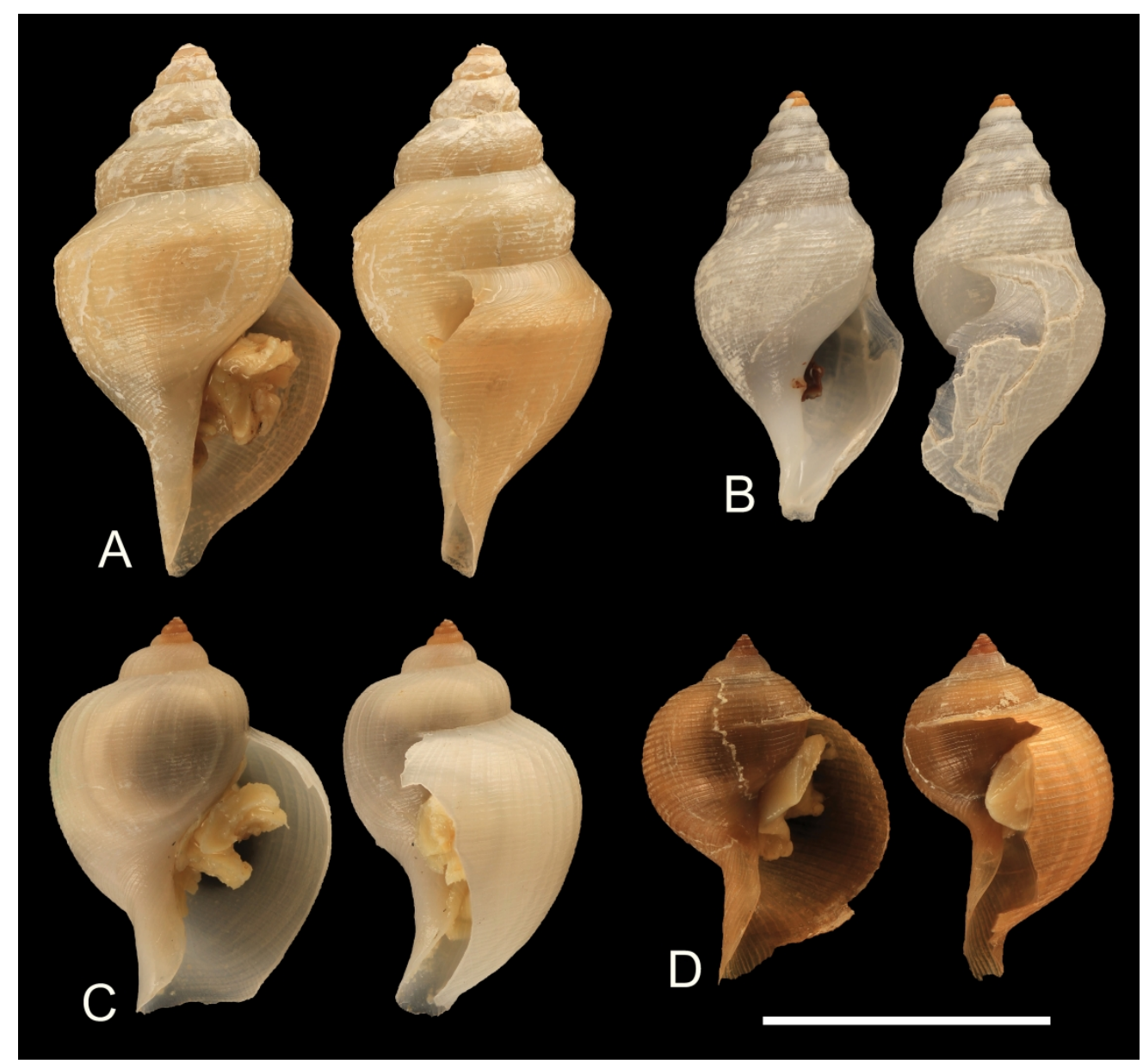

Figure 4. Shells of species described herein. A, Gladiobela angulata n. gen. n. sp., holotype AMS C.571651; B, Pueridaphne cirrisulcata n. gen. n. sp., holotype AMS C.572165; C, Globodaphne pomum n. gen. n. sp., holotype AMS C.482283; D, Trochodaphne cuprosa n. gen. n. sp., holotype AMS C.571611. Scale bar 10 $\mathrm{mm}$.

$167 \times 156 \mathrm{~mm}(600 \times 600 \mathrm{DPI})$ 
Figure 5. Larval shells of species described herein. A, Trochodaphne cuprosa n. gen. n. sp., holotype AMS C.571611; B, Globodaphne pomum n. gen. n. sp., holotype AMS C.482283; C, Pagodibela maia n. gen. $n$. sp., holotype AMS C.571678; D, Pueridaphne cirrisulcata n. gen. n. sp., paratype AMS C.563103; E, Austrobela rufa n. gen. n. sp., paratype AMS C. 571681 . Scale bar $=500 \mu \mathrm{m}$.

$83 \times 72 \mathrm{~mm}(600 \times 600 \mathrm{DPI})$ 
Figure 6. Hypodermic teeth of species described herein. A, Aplotoma braevitentaculata n. gen. n. sp., holotype AMS C.571635; C, Pueridaphne cirrisulcata n. gen. n. sp., paratype AMS C.571609; D: Austrobela rufa n. gen. n. sp.: holotype AMS C.571709 (left), paratype AMS C.571679 (right); B, Gladiobela angulata n. gen. n. sp., paratype AMS C.571737; E, Pagodibela maia n. gen. n. sp., holotype AMS C.571678; F, Fusobela parvioculata n. gen. n. sp., holotype TMAG E59231; G, Biconitoma cretosa n. gen. n. sp., holotype AMS C.482313; H, Austrotheta crassidentata n. gen. n. sp., holotype AMS C.519302. Scale bar = $50 \mu \mathrm{m}$. 


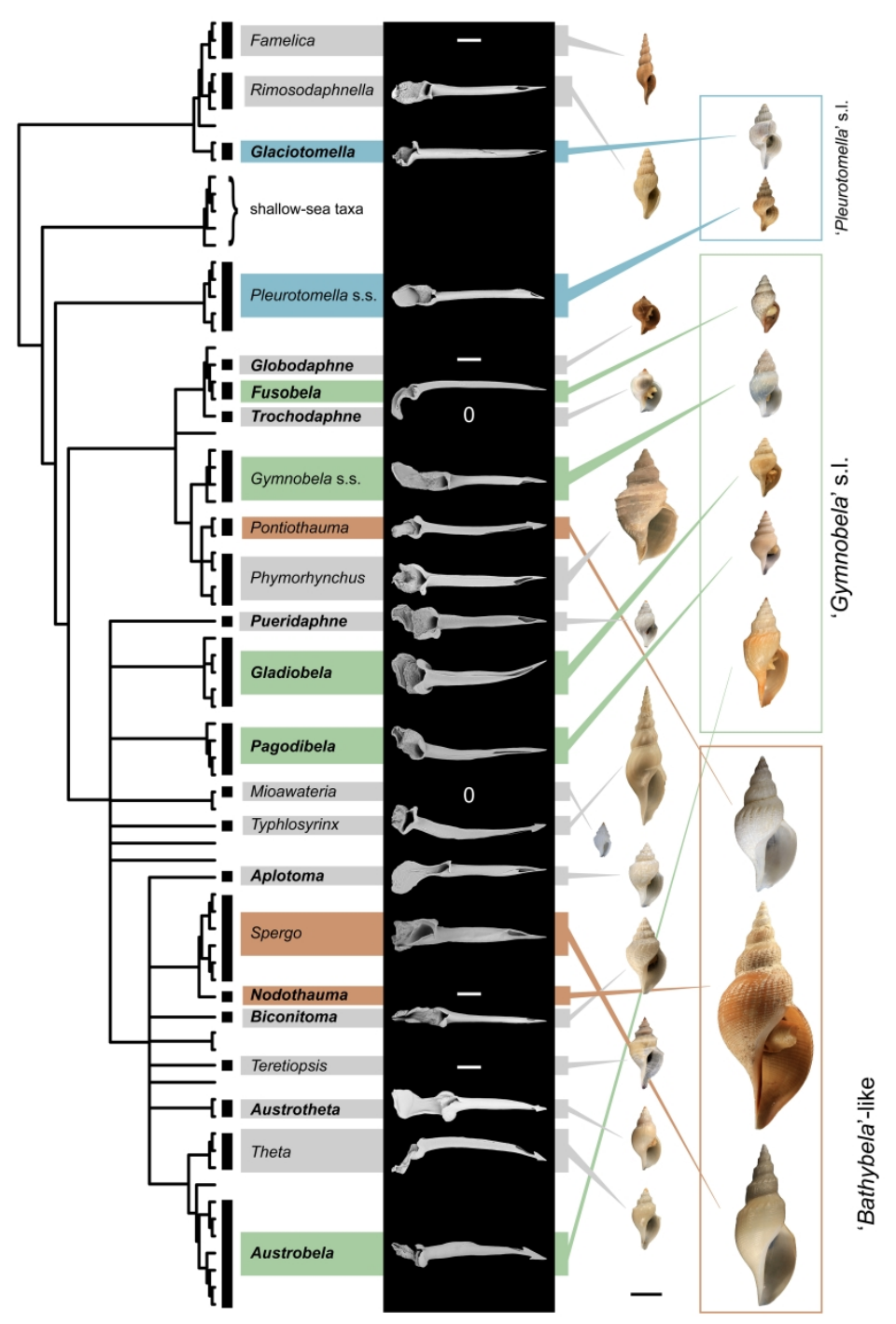

Figure 7. Shell (scalebar $=10 \mathrm{~mm}$ ) and radula (not in scale) of deep-sea raphitomids mapped on genuslevel clades (black boxes) of the strict consensus cladogram for the ML and BI analyses. For most clades attributed to newly described genera, images of the genus type specimen are shown (see Systematics). The radula of Glaciotomella n. gen. sp. 1 (SAMA D44120) is shown instead of that of the type species. For clades assigned to named genera, shell and radula are shown from specimens present in the analysis of Fig. 2 or from congeneric vouchers of the following species: Pleurotomella sp. 2 (WAM S32236, shell; AMS C.487456, radula); Famelica sp. 1 (AMS C.482253); Rimosodaphnella sp. 1 (AMS C.571613); Pontiothauma sp. 2 (AMS C.571641, shell; AMS C.519398, radula); Phymorhynchus cingulatus (Dall, 1890) (AMS C.571764, shell; AMS C.571665, radula); Gymnobela n. sp. 4 (AMS C.571666, shell; AMS C.482314, radula ); Typhlosyrinx sp. (AMS C.519335); Mioawateria sp. (MNHN IM-2013-68769); Teretiopsis sp. (AMS C.571622); Austrotheta crassidentata n. gen n. sp. (AMS C.519302); Spergo sp. 1 (AMS C.519290); Theta lyronuclea (Clarke, 1959)

(AMS C572169, shell; AMS C.571733, radula). Note that two separate clades are attributed to Phymorhynchus (see Discussion). Images are not shown for clades of uncertain generic attribution and not containing Australian samples. Shell images of conchologically cryptic genera groups (see Discussions) are 
1

2

3

4

5

6

7

8

9

10

11

12

13

14

15

16

17

18

19

20

21

22

23

24

25

26

27

28

29

30

31

32

33

34

35

36

37

38

39

40

41

42

43

44

45

46

47

48

49

50

51

52

53

54

55

56

57

58

59

60

grouped in boxes. Dashes represent radula absence for the genus and zeros indicate missing data.

$167 \times 224 \mathrm{~mm}(600 \times 600 \mathrm{DPI})$ 


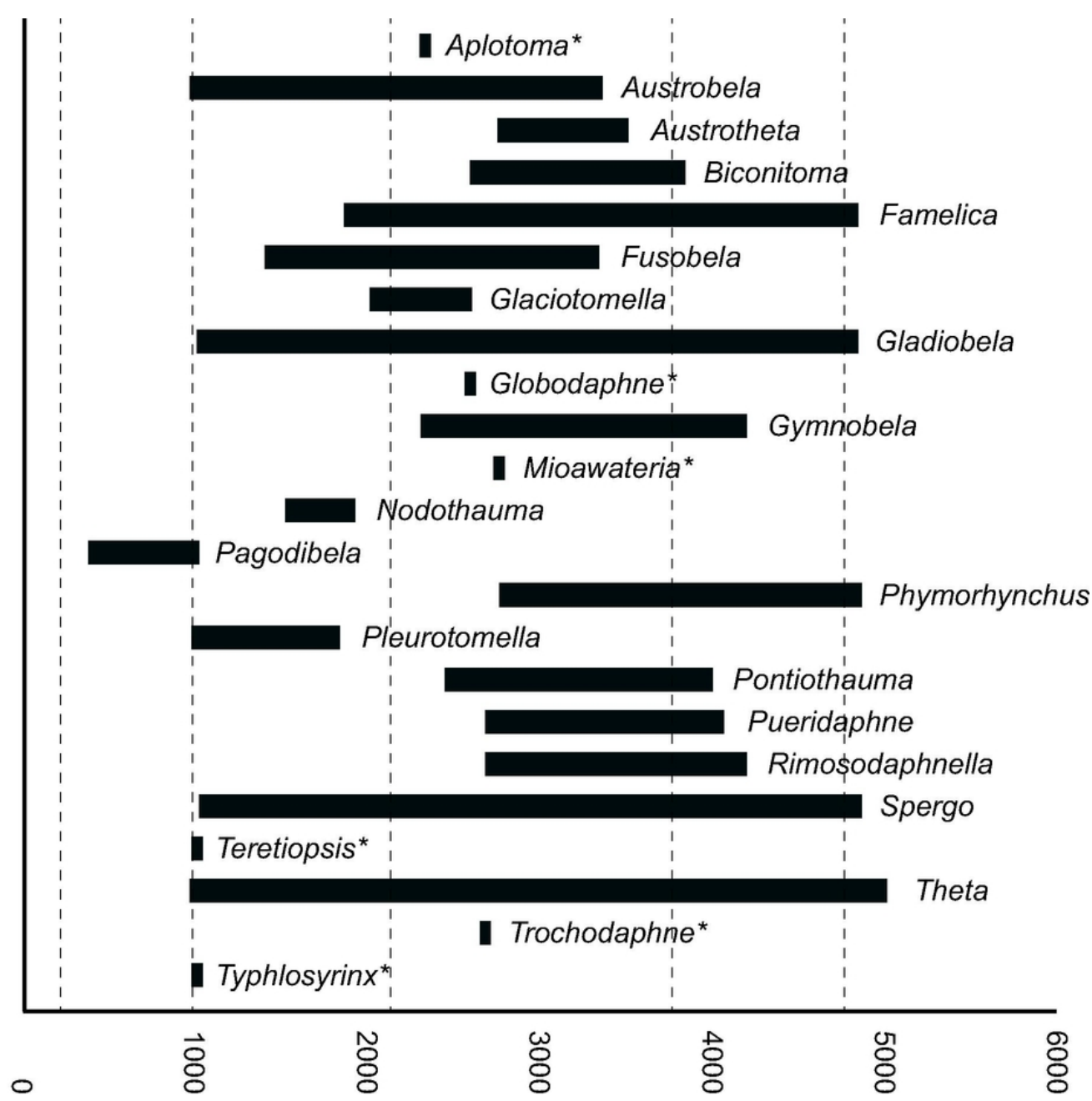

Figure 8. Bathymetric ranges of genera of Raphitomidae in SE temperate Australian waters. A, Continental shelf; B, upper continental slope; C, lower continental slope; D, continental rise; E, abyssal plain; F, hadal depths. Asterisks mark genera known from one sample only. 


\begin{tabular}{|c|c|c|c|c|c|c|c|c|c|c|c|}
\hline$\overline{\text { Family }}$ & Taxon & Museum & Registration no. & 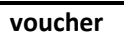 & Locality/Expedition & BOLD id & COI & 165 & 125 & H3 & 285 \\
\hline 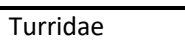 & Turris babylonia (Linnaeus, 1758) & MNHN & IM-2007-17754 & & $\begin{array}{l}\text { Philippines, (9.618, 123.877), 8-22 m, Panglao 2004, R42. } \\
\end{array}$ & CONO226-08 & EU015677 & HQ401715 & HQ401652 & EU015786 & EU015562 \\
\hline \multirow[t]{2}{*}{ Mangelidae } & Citharomangelia planilabroides (Tryon, 1884) & MNHN & IM-2007-17896 & & Philippines, $(9.56,123.725)$, 0-3 m, Panglao 2004, D5. & CONO219-08 & EU015670 & MN320420 & MN322387 & EU015779 & EU015555 \\
\hline & Lienardia cf. mighelsi Iredale \& Tomlin, 1917 & MNHN & IM-2007-17897 & & Philippines, $(9.618,123.768), 3$ m, Panglao 2004, B8. & CONO220-08 & EU015671 & MN942688 & MN942694 & EU015780 & EU015556 \\
\hline \multirow[t]{43}{*}{ Raphitomidae } & Aplotoma braevitentaculata n. gen. n. sp. & AMS & c.571635 & $\mathrm{Ht}$ & Australia, VIC, East Gippsland CMR, (-37.792, 150.382), 2338 m, IN2017_V03. & - & MN983163 & MN985714 & MN985653 & MN971739 & - \\
\hline & Austrobela n. gen. sp. & AMS & C.519275 & & Australia, NSW, Coral Sea CMR, (-23.587, 154.194), 1013 m, IN2017_V03 & - & MN983164 & MN985715 & MN985654 & MN971740 & MN985775 \\
\hline & Austrobela n. gen. sp. 1 & AMS & C.519400 & & Australia, Qld, Coral Sea CMR, (-23.631, 154.66), 1770 m, IN2017_V03. & - & 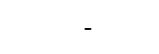 & MN985716 & MN985655 & MN971741 & MN985776 \\
\hline & Austrobela n. gen. sp. 2 & AMS & C.571693 & & Australia, GAB, (-34.074, 129.182), 2649 m, IN2015_C01. & - & MN983165 & MN985717 & MN985656 & MN971742 & MN985777 \\
\hline & Austrobela n. gen. sp. 3 & AMS & c.571670 & & Australia, GAB, (-34.823, 132.692), $1015 \mathrm{~m}$, IN2015_C02. & - & MN983166 & MN985718 & MN985657 & MN971743 & MN985778 \\
\hline & Austrobela n. gen. sp. 4 & AMS & C.571644 & & Australia, NSW, Hunter CMR, (-32.575, 153.162), 2595 m, IN2017_V03. & - & MN983167 & MN985719 & MN985658 & MN971744 & - \\
\hline & Austrobela n. gen. sp. 5 & AMS & C.571682 & & Australia, NSW, off Byron Bay, (-28.677, 154.203), 2587 m, IN2017_V03. & - & - & MN985720 & MN985659 & MN971745 & \\
\hline & Austrobela rufa n. gen. n. sp. & AMS & c.571699 & Pt & Australia, GAB, (-35.345, 134.045), $1509 \mathrm{~m}$, IN2015_C02. & - & MN983168 & MN985721 & MN985660 & MN971746 & MN985779 \\
\hline & Austrotheta crassidentata n. gen n. sp. & AMS & C.519302 & $\mathrm{Ht}$ & Australia, TAS, Freycinet CMR, (-41.731, 149.12), 2820 m, IN2017_V03. & - & MT260886 & MN985768 & MN985707 & MN971792 & MN985812 \\
\hline & Austrotheta n. gen. sp. 1 & AMS & C.572174 & & Australia, GAB, (-34.574, 129.572), 3540 m, IN2015_C01. & - & MN983208 & MN985765 & MN985704 & MN971789 & MN985809 \\
\hline & Biconitoma cretosa n. sp. & AMS & C.482313 & $\mathrm{Ht}$ & Australia, NSW, off Byron Bay, (-28.677, 154.203), 2587 m, IN2017_V03. & - & MN983169 & MN985722 & MN985661 & MN971747 & MN985780 \\
\hline & Eucyclotoma cymatodes (Hervier, 1897) & MNHN & IM-2007-17903 & & Philippines, (9.49, 123.933), 6-8 m, Panglao 2004, S12. & CONO227-08 & EU015678 & нQ401676 & HQ401610 & EU015787 & EU015563 \\
\hline & Famelica sp. 1 & AMS & C.482253 & & Australia, ald, off Moreton Bay, $(-26.946,153.945), 2520$ m, IN2017_V03. & - & MN983170 & MN985723 & MN985662 & MN971748 & - \\
\hline & Famelica sp. 2 & SAMA & D49339 & & Australia, GAB, (-34.768, 130.713), 1873 m, IN2015_C01. & - & MN983171 & MN985724 & MN985663 & MN971749 & MN985781 \\
\hline & Famelica pacifica Sysoev \& Kantor, 1987 & AMS & c.571629 & & Australia, TAS, Flinders CMR, (-40.473, 149.397), 4114 m, IN2017_V03. & - & MN983172 & MN985725 & MN985664 & MN971750 & MN985782 \\
\hline & Fusobela cf. parvioculata n. gen. n. sp. & AMS & C.571736 & Pt & Australia, GAB, (-34.452, 129.492), 3350 m, IN2015_C01. & - & - & MN985726 & MN985665 & MN971751 & \\
\hline & Fusobela parvioculata n. gen. n. sp. & TMAG & E59231 & $\mathrm{Ht}$ & Australia, Tasmania, Flat area S of Brians, (-44.239, 147.293), 1414 m, IN2018_V06. & - & MN983173 & MN985727 & MN985666 & MN971752 & - \\
\hline & Glaciotomella investigator $\mathrm{n} . \mathbf{s p}$. & AMS & c.571621 & $\mathrm{Ht}$ & Australia, NSW, Hunter CMR, $(-32.575,153.162), 2595 \mathrm{~m}$, IN2017_V03. & - & MN983178 & MN985731 & MN985670 & & MN985784 \\
\hline & Glaciotomella sp. 1 n. gen. n. sp. & SAMA & D44120 & & Australia, GAB, (-34.625, 130.28), $2007 \mathrm{~m}$, IN2015_C02. & - & MN983179 & MN985732 & MN985671 & MN971756 & MN985785 \\
\hline & Gladiobela angulata n. gen. n. sp. & AMS & C.571651 & $\mathrm{Ht}$ & Australia, NSW, Hunter CMR, (-32.575, 153.162), $2595 \mathrm{~m}$, IN2017_v03. & - & MN983180 & MN985733 & MN985672 & MN971757 & \\
\hline & Gladiobela n. gen. sp. 1 & AMS & c.571697 & & Australia, VIC, East Gippsland CMR, (-38.479, 150.185), 3850 m, IN2017_V03. & - & MN983181 & MN985734 & MN985673 & MN971758 & MN985786 \\
\hline & Gladiobela n. gen. sp. 2 & AMS & c.571717 & & Australia, NSW, off Bermagui, (-36.351, 150.914), 4747 m, IN2017_V03. & - & MN983182 & MN985735 & MN985674 & MN971759 & MN985787 \\
\hline & Gladiobela n. gen. sp. 3 & AMS & C.571683 & & Australia, NSW, Hunter CMR, (-32.138, 153.527), 3980 m, IN2017_V03. & - & MN983183 & MN985736 & MN985675 & MN971760 & MN985788 \\
\hline & Gladiobela n. gen. sp. 4 & AMS & c.482311 & & Australia, NSW, Hunter CMR, (-32.479, 152.994), $1006 \mathrm{~m}$, IN2017_V03. & 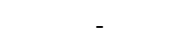 & MN983184 & MN985737 & MN985676 & MN971761 & - \\
\hline & Globodaphne pomum n. gen. n. sp. & AMS & C.482283 & $\mathrm{Ht}$ & Australia, NSW, Hunter CMR, (-32.575, 153.162), 2595 m, IN2017_V03. & - & MN983185 & MN985738 & MN985677 & MN971762 & MN985789 \\
\hline & Glyphostomoides sp. & MNHN & IM-2007-17892 & & Philippines, (9.5, 123.833), 100-138 m, Panglao 2004, т39. & CONO281-08 & EU015715 & HQ401681 & & EU015824 & EU015600 \\
\hline & Gymnobela sp. 1 & AMS & C.482286 & & Australia, NSW, Jervis CMR, (-35.114, 151.469), 3952 m, IN2017_V03. & - & - & MN985739 & MN985678 & MN971763 & MN985790 \\
\hline & Gymnobela sp. 2 & AMS & C.519355 & & Australia, NSW, Jervis CMR, (-35.333, 151.258), 2650 m, IN2017_V03. & - & - & MN985740 & MN985679 & MN971764 & - \\
\hline & Gymnobela sp. 3 & AMS & c.571649 & & Australia, TAS, Bass Strait, (-39.552, 149.553), 4197 m, IN2017_V03. & - & & MN985741 & MN985680 & MN971765 & MN985791 \\
\hline & Gymnobela sp. 4 & AMS & C.571702 & & Australia, NSW, Jervis CMR, (-35.333, 151.258), 2650 m, IN2017_V03. & 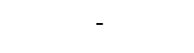 & . & MN985742 & MN985681 & MN971766 & MN985792 \\
\hline & Mioawateria sp. 1 & AMS & C.482239 & & Australia, VIC, East Gippsland CMR, (-37.815, 150.373), 2746 m, IN2017_V03. & - & MN983186 & MN985743 & MN985682 & MN971767 & MN985793 \\
\hline & Nodothauma magnifica n. gen. n. sp. & AMS & C.532707 & $\mathrm{Ht}$ & Australia, GAB, $(-35.558,134.083), 1927 \mathrm{~m}, \mathrm{NN2015} \_\mathrm{CO} 1$ & - & MN983187 & MN985744 & MN985683 & MN971768 & - \\
\hline & Pagodibela maia n. gen. n. sp. & AMS & C.571678 & $\mathrm{Ht}$ & Australia, Qld, Coral Sea CMR, (-23.587, 154.194), 1013 m, IN2017_V03. & - & MN983188 & MN985745 & MN985684 & MN971769 & \\
\hline & Pagodibela n. gen. sp. 1 & SAMA & D44173 & & Australia, GAB, (-35.043, 134.079), $367 \mathrm{~m}$, IN2015_C01. & - & MN983189 & MN985746 & MN985685 & MN971770 & MN985794 \\
\hline & Pagodibela n. gen. sp. 2 & AMS & C.519402 & & Australia, Qld, Coral Sea CMR, (-23.587, 154.194), 1013 m, IN2017_V03. & - & MN983190 & MN985747 & MN985686 & MN971771 & MN985795 \\
\hline & Pagodibela n. gen. sp. & MNHN & IM-2007-17844 & & New Caledonia, (-20.967, 160.967), 641-652 m, EBISCO, CP2645. & CONO186-08 & EU015652 & MN942687 & MN942693 & EU015760 & EU015536 \\
\hline & Phymorhynchus cingulatus (Dall, 1890) & AMS & C.571764 & & Australia, TAS, Bass Strait, (-39.552, 149.553), 4133 m, IN2017_V03. & - & & MN985748 & MN985687 & MN971772 & MN985796 \\
\hline & Phymorhynchus moskalevi Sysoev \& Kantor, 1995 & MNHN & IM-2013-41884 & & North Atlantic Ocean, (23.367, -44.95), 3466 m, BICOSE, PL568_NAS. & CONO2814-19 & MN942683 & MN942686 & MN942692 & MN942935 & \\
\hline & Phymorhynchus sp. 1 & AMS & c.571711 & & Australia, VIC, East Gippsland CMR, (-38.479, 150.185), 3850 m, IN2017_V03. & - & MN983191 & MN985749 & MN985688 & MN971773 & MN985797 \\
\hline & Phymorhynchus sp. 2 & AMS & C.571627 & & Australia, NSW, off Bermagui, (-36.351, 150.914), 4851 m, IN2017_V03. & - & MN983192 & MN985750 & MN985689 & MN971774 & MN985798 \\
\hline & Pleurotomella sp. 1 & SAMA & D63333 & & Australia, GAB, (-34.738, 131.841), 1350 m, IN2015_C01. & - & MN983193 & MN985751 & MN985690 & MN971775 & - \\
\hline & Pleurotomella sp. 2 & WAM & \$32236 & & Australia, WA, Off Houtman Abrolhos Islands, (-29.061, 113.636), $1000 \mathrm{~m}$, SS1005. & - & MN983194 & MN985752 & MN985691 & MN971776 & - \\
\hline & Pleurotomella sp. & MNHN & IM-2007-17848 & & New Caledonia, (-20.083, 160.333), 627-741 m, EBISCO, DW2625. & CONO191-08 & EU015657 & HQ401701 & HQ401640 & EU015765 & EU015541 \\
\hline
\end{tabular}




\begin{tabular}{|c|c|c|}
\hline Ponthiothauma sp. 1 & AMS & C.482298 \\
\hline Ponthiothauma sp. 2 & AMS & c.482289 \\
\hline Pseudodaphnella aureotincta (Hervier, 1897) & MNHN & IM-2007-17878 \\
\hline Pseudodaphnella crypta Fedosov \& Puillandre, 2012 & MNHN & IM-2007-17871 \\
\hline Pueridaphne cirrisulcata n. gen. n. sp. & AMS & c.572165 \\
\hline Rimosodaphnella sp. 1 & AMS & c.571613 \\
\hline Rimosodaphnella sp. 2 & AMS & c.571685 \\
\hline Rimosodaphnella sp. & MNHN & IM-2007-17836 \\
\hline Spergo fusiformis (Habe, 1962) & AMS & c.482154 \\
\hline Spergo sp. 1 & AMS & c.519290 \\
\hline Spergo sp. 2 & AMS & c.519331 \\
\hline Spergo sp. 3 & AMS & c.519392 \\
\hline Spergo sp. 4 & AMS & c.571638 \\
\hline Spergo sp. & MNHN & IM-2007-17841 \\
\hline Taranis sp. & MNHN & IM-2007-42296 \\
\hline Teretiopsis sp. & AMS & c.571622 \\
\hline Thatcheria mirabilis Angas, 1877 & MNHN & IM-2007-17924 \\
\hline Theta Iyronuclea (A. H. Clarke, 1959) & AMS & c.482290 \\
\hline Theta sp. 2 & AMS & c.532711 \\
\hline Theta sp. 3 & AMS & c.571657 \\
\hline Thetidos tridentata Fedosov \& Puillandre, 2012 & MNHN & IM-2007-17880 \\
\hline Trochodaphne cuprosa n. gen. n. sp. & AMS & c.571611 \\
\hline Typhlosyrinx sp. & AMS & c.519335 \\
\hline Unassigned genus and species & AMS & c.571643 \\
\hline Unassigned genus and species & AMS & c.519362 \\
\hline Unassigned genus and species & AMS & c.571734 \\
\hline Unassigned genus and species & MNHN & IM-2007-17927 \\
\hline Unassigned genus and species & MNHN & IM-2013-19998 \\
\hline Unassigned genus and species & MNHN & IM-2013-52046 \\
\hline Unassigned genus and species & ZSM & mol_20021232 \\
\hline Unassigned genus and species & ZSM & mol_20191328 \\
\hline Unassigned genus and species & ZSM & mol_20021548 \\
\hline Veprecula cf. spanionema & MNHN & IM-2007-17883 \\
\hline
\end{tabular}

Australia, NSW, Central Eastern CMR, (-30.264, 153.87), 4481 m, IN2017_V03. Australia, NSW, Central Eastern CMR, (-30.098, 153.899), 2429 m, IN2017_V03. Philippines, (9.49, 123.935), $16 \mathrm{~m}$, Panglao 2004, B25.

Philippines, (9.692, 123.85), $21 \mathrm{~m}$, Panglao 2004, 525.

Ht Australia, GAB, (-34.452, 129.492), $3350 \mathrm{~m}$, IN2015_C01. Australia, NSW, Jervis CMR, (-35.333, 151.258), 2650 m, IN2017_V03. Australia, TAS, Bass Strait, (-39.552, 149.553), $4197 \mathrm{~m}$, IN2017_V03. Vanuatu, off Epi, (-16.633, 167.950), 618-641m, BOA1, CP 2462. Australia, NSW, Coral Sea CMR, (-23.587, 154.194), 1013 m, IN2017_v03. Australia, TAS, Freycinet CMR, (-41.731, 149.12), $2820 \mathrm{~m}$, IN2017_V03. Australia, TAS, Bass Strait, (-39.552, 149.553), $4197 \mathrm{~m}$, IN2017_V03. Australia, TAS, Flinders CMR, (-40.473, 149.397), $4114 \mathrm{~m}$, IN2017_V03. Australia, NSW, Hunter CMR, (-32.575, 153.162), $2595 \mathrm{~m}$, IN2017_V03. New Caledonia, $(-21.533,162.5), 458-750 \mathrm{~m}$, EBISCO, CP2648.

Philippines, Aurora, off Dipaculao, (15.95, 121.833) 473 m. AURORA 2007, CP2749. Australia, Qld, Coral Sea CMR, (-23.587, 154.194), 1013 m, IN2017_V03. Solomon Islands, (-8.283, 160), 464-523 m, SALOMON 2, CP2184, Australia, NSW, lervis CMR, (-35.114, 151.469), 3952 m, IN2017_V03. Australia, GAB, (-35.818, 134.109), $2852 \mathrm{~m}$, IN2015_C02.

Australia, NSW, Hunter CMR, (-32.575, 153.162), 2595 m, IN2017_V03. Philippines, (9.515, 123.687), 90-110 m, Panglao 2004, L46.

Ht Australia, NSW, Jervis CMR, (-35.333, 151.258), $2650 \mathrm{~m}$, IN2017_v03 Australia, NSW, off Byron Bay, (-28.054, 154.083), 999 m, IN2017. Australia, VIC, East Gippsland CMR, (-38.479, 150.185), 3850 m, IN2017_V03. Australia, NSW, off Bermagui, (-36.355, 150.644), 2821 m, IN2017_V03. Australia, GAB, (-34.452, 129.492), $3350 \mathrm{~m}$, IN2015 C01.

Solomon Islands, (-8.067, 156.917), 399-427 m, SALOMON 2, CP2260.

Papua New Guinea, $(-5.5,146.15), 400$ m, PAPUA NIUGINI, CP4020.

Papua New Guinea, (-3.317, 143.45), 422-425 m, PAPUA NIUGINI, CP4049.

Antarctica, (-54.023, -62.022), $272 \mathrm{~m}$, LAMPOS, ANT XIX-5.

Antarctica, (-54.023, -62.022), 272 m, LAMPOS, ANT XIX-5,

Antarctica, Drake-Strasse (-54.504, -56.137), 286.3 m, LAMPOS, ANT XIX. Philippines, $(9.515,123.687)$, 90-110 m, Panglao 2004, L46.

\begin{tabular}{|c|c|c|c|c|c|}
\hline & MN983196 & MN985753 & MN985692 & MN971777 & MN985799 \\
\hline & 9983197 & MN985754 & MN985693 & MN971778 & MN985800 \\
\hline $59-08$ & EU015700 & HQ401688 & HQ401624 & EU015809 & EU015585 \\
\hline \multirow[t]{4}{*}{ CONO251-08 } & EU015693 & & MN942691 & EU015802 & EU015578 \\
\hline & MN983198 & MN985755 & MN985694 & MN971779 & \\
\hline & MN983199 & MN985756 & MN985695 & MN971780 & MN985801 \\
\hline & MN983200 & MN985757 & MN985696 & MN971781 & MN985802 \\
\hline NO150-08 & EU015645 & HQ401704 & - & EU015754 & EU015529 \\
\hline- & MN983201 & MN985758 & MN985697 & MN971782 & MN985803 \\
\hline - & MN983202 & MN985759 & MN985698 & MN971783 & MN985804 \\
\hline - & MN983203 & MN985760 & MN985699 & MN971784 & MN985805 \\
\hline- & MN983204 & MN985761 & MN985700 & MN971785 & MN985806 \\
\hline & MN983205 & MN985762 & MN985701 & MN971786 & MN985807 \\
\hline CONO184-08 & EU015650 & HQ401682 & - & EU015759 & EU015534 \\
\hline \multirow[t]{2}{*}{ CONO561-08 } & HQ401584 & HQ401707 & HQ401645 & - & MN868947 \\
\hline & MN983206 & MN985763 & MN985702 & MN971787 & \\
\hline CONO349-08 & EU015736 & FJ868138 & FJ868124 & EU015843 & EU015621 \\
\hline - & MN983207 & MN985764 & MN985703 & MN971788 & MN985808 \\
\hline - & MN983209 & MN985766 & MN985705 & MN971790 & MN985810 \\
\hline- & MN983210 & MN985767 & MN985706 & MN971791 & MN985811 \\
\hline \multirow[t]{6}{*}{ CONO267-08 } & EU015702 & & MN942690 & EU015811 & EU015587 \\
\hline & MN983211 & MN985770 & MN985709 & MN971794 & MN985813 \\
\hline & MN983212 & MN985771 & MN985710 & MN971795 & \\
\hline & MN983175 & MN985728 & MN985667 & MN971796 & MN985783 \\
\hline & MN983174 & MN985729 & MN985668 & MN971755 & \\
\hline & MN983176 & MN985730 & MN985669 & MN971754 & \\
\hline CONO360-08 & EU015740 & HQ401674 & HQ401607 & EU015847 & EU015625 \\
\hline \multirow{5}{*}{$\begin{array}{l}\text { MITRIONO-15 } \\
\text { MIT-19 }\end{array}$} & & MN942689 & - & MN942936 & MN868946 \\
\hline & KR087296 & KR088045 & KR087382 & KR088123 & \\
\hline & - & MN985774 & MN985713 & MN971797 & EU015562 \\
\hline & MN983177 & MN985773 & MN985712 & MN971753 & EU015529 \\
\hline & MN983195 & MN985772 & MN985711 & & EU015534 \\
\hline-08 & EU015705 & HQ401717 & & EU015814 & EU015590 \\
\hline
\end{tabular}

